Şırnak Üniversitesi

İlahiyat Fakültesi Dergisi

Cilt: 11, Sayı: 25, Aralık 2020

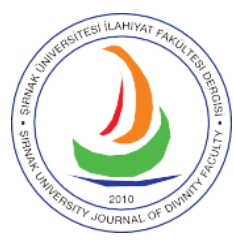

e-ISSN 2667-6575
Şırnak University

Journal of Divinity Faculty

Volume: 11, Issue: 25, December 2020

\title{
Hulefâ-yi Râşidîn Döneminde İktâ Uygulamaları
}

Iqtā Applications in the Period of the Rashid Caliphs

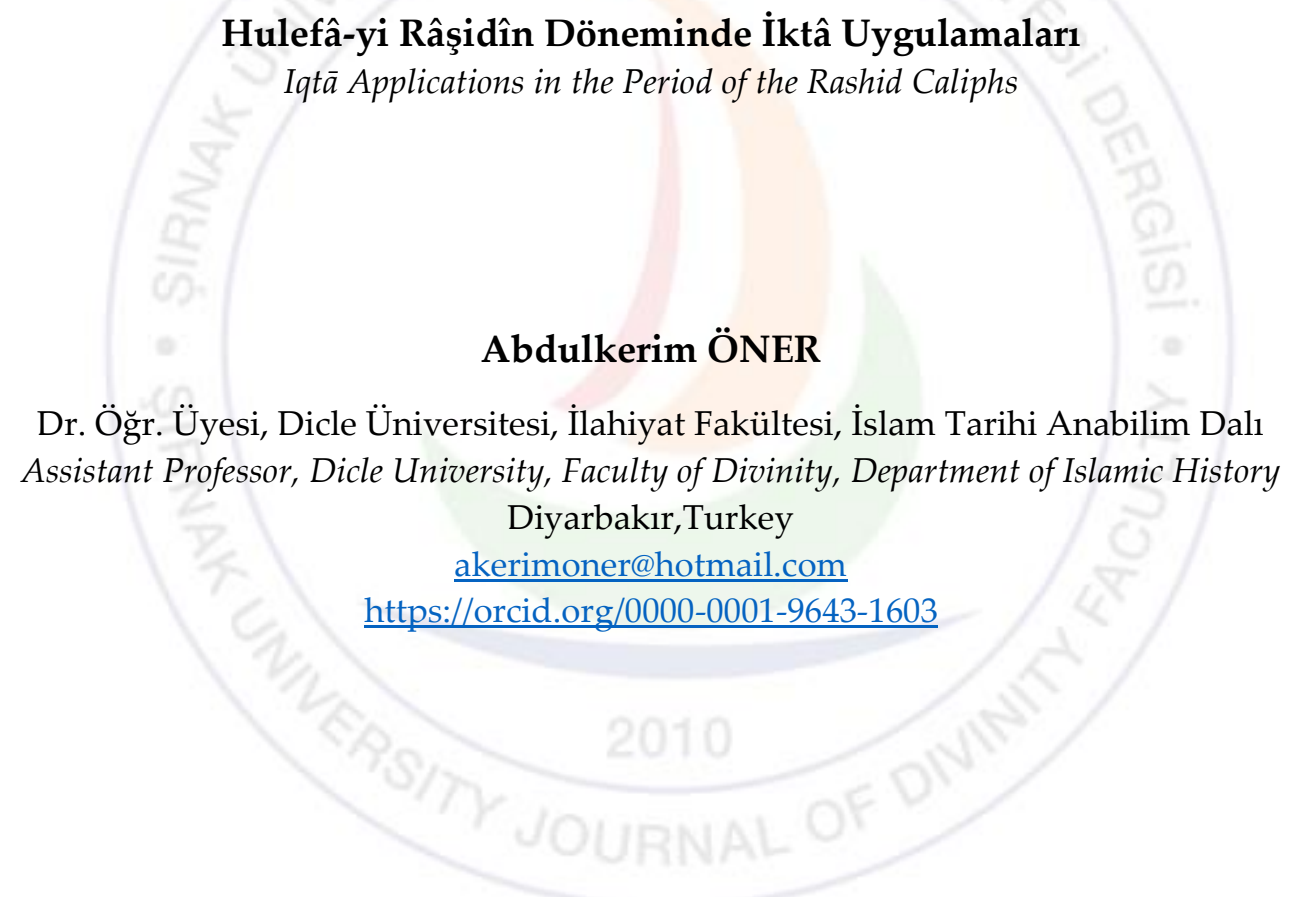

Makale Bilgisi / Article Information

Makale Türü / Article Types: Araştırma Makalesi / Research Article

Geliş Tarihi / Received: 14 Eylül / September 2020

Kabul Tarihi / Accepted: 9 Kasim / November 2020

Yayın Tarihi / Published: 15 Aralık / December 2020

Cilt / Volume: 11 Sayı / Issue: 25 Sayfa / Pages: 457-486

Atıf / Cite as: Öner, Abdülkerim. “Hulefâ-yi Râşidîn Döneminde İktâ Uygulamaları [Iqtā Applications in the Period of the Rashid Caliphs]". Şırnak Üniversitesi İlahiyat Fakültesi Dergisi - Şırnak University Journal of Divinity Faculty 11/25 (December 2020), 457-486. https://doi.org/10.35415/sirnakifd.794994

Etik Beyanı / Ethics Declaration: Bu makalede bilimsel araştırma ve yayın etiği ilkelerine riayet edilmiştir. Makale etik izin gerektirmeyen bir çalışma olup en az iki hakem tarafından incelenmiş ve intihal içermediği teyit edilmiştir./ In this article, the principles of scientific research and publication ethics are respected. The article is a study that does not require ethical permission. It has been reviewed by at least two referees and was confirmed that it did not contain plagiarism.

Copyright ( ) Published by Şırnak Üniversitesi, İlahiyat Fakültesi / Şırnak, Türkiye (Şırnak University, Faculty of Divinity, Şırnak, 73000 Turkey). 


\title{
Öz
}

İslâm öncesi dönemde Hicaz bölgesinde belirli bir devlet sistemi yoktu. Bunun için çeşitli amaçlarla halka dağıtılan toprak parçası anlamında kullanılan iktâ kavramından bahsedilemez. Bununla birlikte Hz. Peygamber zamanında bölge idari bir merkeze kavuşturulmuş ve topraktan verimli bir şekilde istifade etmek için girişimlerde bulunulmuştur. Sahipsiz topraklar muhacirler arasında taksim edilmiş ve tarıma kazandırılmıştır. Hz. Peygamber, halkın ihtiyaçlarını gidermek amacıyla çeşitli vesilelerle toprak iktâ etmiştir. Verdiği arazilerin büyük çoğunluğu ise iskân amaçlıydı. Bütün halkın istifade edeceği yerleri iktâ olarak vermekten kaçınmıştır. Hulefâ-yi Râşidîn Dönemi'nde iktâ olarak verilen toprakların geneli, herhangi bir mülkiyetin söz konusu olmadığı mevât topraklar ve savâfî arazilerdi. Bu arazilerin verilme nedeni genel olarak fethedilen yerlerde yaşayanların gönüllerini İslamiyete ısındırmak, yeni şehirlerin kurulmasını teşvik etmek ve sınır boylarına yerleştirilen askerlerin ihtiyaçlarını karşılamaktı. Ayrıca hazineye gelir getirmesi amacıyla bazı araziler iktâ olarak dağıtılmış ve bunlar daha çok savâfî topraklardan verilmiştir. Gelir getirmesi amacıyla verlien arazilerin mülkiyet hakkı halifelerde olup tasarruf yetkisi araziyi iktâ olarak alanlara aitti. İşlemek amacıyla toprakları alanlar, şartlarını yerine getirdikleri müddetçe bu topraklar üzerinde hak sahibiydiler. Ancak bu toprakları üç sene atıl bırakıp ziraat yapmadıkları takdirde yöneticiler, bu arazileri ellerinden alıp başka kişilere veriyorlard1.

Anahtar Kelimeler: İslâm Tarihi, Hulefâ-yi Râşidîn, İktâ, İskân, Savâfi, Ölü Arazi, İhyâ.

\begin{abstract}
There was not any specific state system at hidjāz region before Islam. So it cannot be mentioned about Iqtā term that means distributed land between Muslim for specific aims. However, in the time of the Prophet, the region was brought to an administrative center. Attempts have been made to get maximum efficiency from the soil. Empty soils were divided among the immigrants and brought to agriculture. The Prophet took land on various occasions in order to meet the needs of the people. The vast majority of the lands it gave were for settlement purposes. He refrained from giving places where all the people would benefit. The lands that were given as Iqtā during the period of Rashid Caliphs savafi lands that were dead lands and lands that were not owned by any person. The reason for these lands was given to facilitate the Islamization of the conquered places in general, to encourage the establishment of new cities and to meet the needs of the soldiers placed at the border. In addition, some lands were given as Iqtā to bring income to the treasury and the sawafis are mostly composed of these lands. In return, the tax levied is usually the tithe tax, sometimes tribute tax has been levied. Ownership rights of the lands given were in the caliphs and the power of disposition belonged to those who acquired the land as Iqtā. Those who bought the land for cultivation were entitled to these lands as long as they fulfilled their conditions. However, if they left this land empty for three years, the caliphs would take these lands out of their hands and give it to the people they deem appropriate.
\end{abstract}

Keywords: Islamic History, Rashid Caliphs, Iqtā, Settlement, Sawafi, Dead Land, Ihya. 


\section{Extended Abstract}

In the pre-Islamic period, while the tradition of sharing the lands with another person through the iqtā system was widespread in some regions, it was not common across the Hejaz region, where it began to be applied with the rise of Islam. At the behest of Prophet Muhammad (PBUH), the unowned lands in Madinah were primarily given grants of lands to those fleeing Mecca due to the oppression and persecution they suffered there during the birth of Islam in order to provide food and shelter for these refugees. Another reason why this system was applied was that the Beloved Prophet (PBUH) wanted to warm people's hearts to Islam and avert animosity and hostility against Islam, thus rendering potential attackers harmless. Yet another reason was to gain the support of the chiefs of the local tribes that migrated from the places not yet conquered by giving grants of lands to these people as an incentive to conquering new places and absorbing them into the lands of Islam.

Following the conquest of Iraq, Syria, and Egypt during the period of Four Caliphs, the lands, which had remained unclaimed up to that time for various reasons, passed into the ownership of Muslims. Such lands were acknowledged to be sawafi land, meaning that they had no owner at the time of the conquest, and were therefore transferred to the Treasury. Furthermore, abandoned and unproductive lands that had neither been cultivated nor settled in by anyone to claim ownership to them were also acknowledged as mavat (uncultivated land), thus handed over to the Treasury. The lands granted as iqtā were usually sawafi and mavat lands.

For a piece of land to be granted as iqtā, it had to belong to the Treasury, given that allocating private property as iqtā was out of the question. The rationale behind the iqtā system was to provide ownership of land to those who owned none and encourage them to cultivate it, while also urging those already engaged in farming to labour their farms even further. By this means, people would have a legal means of earning money and the economy would prosper.

Muslim territories were expanded extensively with the conquest of new locations during the caliphate of Umar ibn al-Khattab. Due to the difficulties in administering new lands from the capital city of the Islamic State, namely Madinah, a need arose for establishing new cities in these new territories. Various Muslim tribes were brought and settled here and then given grants of lands by the Treasury for settlement purposes. In fact, Muslims were granted these lands as incentives: the hearts of non-Muslims living in newly conquered places would be warmed to Islam and this religion would become permanent here. Furthermore, border security would be maintained through the lands granted to these people for permanent settlement.

Some of the lands granted as abovementioned brought revenues to the Treasury. The lands of Kisra and his relatives, the lands of those dying in or fleeing wars, and those suitable for cultivation were considered as sawafi and therefore granted to some Muslims for establishing farms here. The lands allocated for this purpose were all legally registered.

Since the ownership of the ownerless lands passed to the public, the authorities gave these lands to those people they deemed appropriate on various occasions. Anyone granted a piece of land for cultivation purposes retained the power of disposition over the land as long they met certain conditions. However, the maintenance of their right over these lands depended on how they managed them, which is why the right of those failing to cultivate these lands was taken away. In other words, uncultivated lands were considered as a waste of land as far as the benefit of humanity is concerned. In this case, not only individuals but also 
the state suffered losses. However, these lands had to be constantly cultivated and actively maintained for the common good.

Those in possession of a piece of mavat land that had not been cultivated for three consecutive years were denied all their rights over this land. The logic behind this system, established for the benefit of Muslims and prosperity of the state, worked on the principle that if the time period allocated for cultivation was not used effectively, then all citizens had equal rights over this land. In actual fact, it was thanks to this system that farming was launched on uncultivated lands and sustainability of farming was encouraged.

Farmers granted pieces of land through the iqtā system were generally licensed to be able to cultivate them so that no one else could claim ownership of them. Given that these lands were at the disposal of the Caliph, the farmers had to pay the tax for conquered lands if these lands had been conquered. Likewise, they had to pay tithe tax if these lands were accepted as lands of the tithe. As regards the amount of tax, while the farmers paid the amount determined for the conquered lands according to how they had agreed with the state, they paid one-tenth or one-twentieth of the tax as far as the tithe tax was concerned. This is to say that tax could be obtained both from the lands themselves and the crops harvested from them. 


\section{Giriş}

İnsanlık, yerleşik hayata başladığı ilk günden itibaren toprakla iç içe olmuş ve onun ayrılmaz bir parçası haline gelmiştir. Zira toprak, insanoğlunun hayatını sürdürebilmesi için vazgeçilmez bir unsur olmuştur. Bazı bölgelerdeki toprakların verimli olması, o bölgelerin kıymetini bir kat daha artırmıştır. Bugün Ortadoğu olarak bilinen başta Suriye, Irak ve Mısır gibi yerlerde eskiden beri tarım yapılmış ve toprağa bağlı sınıflar oluşmuştur. Ancak bu coğrafyanın komşusu olan Arabistan yarımadasının Hicaz Bölgesi'nin bazı yerlerinde toprağa bağımlılık istenen boyutta değildi. ${ }^{1}$

İslâm öncesi dönemde bazı devletlerde toprakları iktâ usulüyle bir başkasıyla paylaşma geleneği yaygın olmakla birlikte Arabistan bölgesinde bu sistem pek bilinmiyordu. Zira Hicaz bölgesinde belirli bir devlet mekanizması olmadığı gibi kabilevi bir yaşam kültürü hâkimdi. ${ }^{2}$

İslâm tarihinin ilk dönemlerinden itibaren iktâ uygulamalarının olduğu görülmektedir. Bunun temel dayanak noktası, İslâm'ın insanları çalışmaya teşvik etmesidir. Zira "İnsan için ancak çalıştığının karşılığı vardır."3 ayeti bu gerçeği vurgulamaktadır. İslâm dini, başkasına el açmayı, insanlara yük olmayı ve toplumda sorumsuz bir sınıf oluşturmayı tasvip etmemiştir. Bunun içindir ki Mekke'den Medine'ye hicret etmek zorunda kalan ve yanlarında pek bir şey götüremeyen muhacirler, Medine'de başkasına yük olmadan yaşamlarını sürdürmeye çalışmışlar ve bu amaçla Hz. Peygamberle görüşmüşlerdi. Allah Resulü de onların ihtiyaçlarını gidermek amacıyla uğraş vermiştir. Yaptığı ilk işlerden biri, herhangi birinin mülkiyetinde bulunmayan ve tarıma elverişli olan arazileri tespit etmeye çalışmaktı. Medine halkı, sahibi bulunmayan toprakları, Allah Resul'ünün tasarrufuna bırakmışlard1. ${ }^{4} \mathrm{O}$ da akrabalarını, ailelerini ve mallarını Mekke'de bırakıp inançları uğruna Medine'ye göçen ve geçim sıkıntısı çeken muhacirlere maddi destekte bulunmak amacıyla söz konusu arazilerden uygun gördüğü kişilere iktâ olarak vermiştir. ${ }^{5}$

1 Detaylar için bk. Fatih Oğuzay, "Hz. Peygamber Döneminde Tarım Kültürü", (Sakarya: Sakarya Üniversitesi, Sosyal Bilimler Enstitüsü, Yüksek Lisans Tezi, 2008).

2 M. A. Mannan, İslâm Ekonomisi Teori ve Pratik, çev. Bahri Zengin-Tevfik Ömeroğlu (İstanbul: Fikir Yayınları, 1980), 172.

3 Necm $53 / 39$.

4 Ebû Ubeyd Ebû Ubeyd Kasım b. Sellam, Kitâbü'l-emvâl, thk. Dr. Muhammed Ammare (Beyrut: Darü'ş-Şuruk, 1989), 374.

5 Ebû Yusuf Ya'kub b. İbrahim Ebû Yusuf, Kitabü'l-harâc (Beyrut: Darü'l Ma'rife, 1979), 61; M. A. Mannan, İslâm Ekonomisi Teori ve Pratik, 172. 
Hz. Peygamber'in muhacirlere verdiği ölü arazilerin büyük çoğunluğu iskân amaçlıydı. Zira muhacirlerin Medine'deki en önemi problemi, geçinme ve barınma ihtiyacıydı. Bu ihtiyaçlarının karşılanması için etkili yollardan biri topraktı. Bu konuda Hz. Peygamber, başta Hz. Ebû Bekir, Hz. Ömer ${ }^{6}$ ve Hz. Ali olmak üzere birçok kişiye arazi iktâ etmiştir. ${ }^{8}$

Yahudilere ait bazı yerleşim birimleri, Müslümanların eline geçinceye kadar muhacirlerin ciddi sıkıntı yaşadığı bilinmektedir. Onların geride bıraktıkları toprakların büyük bir kısmı muhacirler arasında pay edilmiştir. ${ }^{9}$

Hz. Peygamber, ölü arazileri ihyâ etmek, daha verimli hale getirmek ${ }^{10}$ ve üretimi artırmak amacıyla birçok toprak parçasını iktâ olarak vermiştir. ${ }^{11}$ Bu amaçla Ensar'dan Salit adında bir sahâbîye hem ihtiyaçlarını gidermesi hem de bölgeyi tarıma kazandırması amacıyla bir arazi parçasını iktâ etmiştir. O da araziyi imar etmiş ancak verilen arazinin kendisini Allah Resul'ünün sohbetinden mahrum bıraktığı gerekçesiyle geri vermiştir. Bunun üzerine söz konusu araziyi Zübeyr b. Avvâm isteyince Allah Resulü de bu araziyi ona vermiştir. ${ }^{12}$

6 Ebû Yusuf, Kitabü'l-harâc, 61.

7 Ebü'l-Hasen Nûrüddîn Alî b. Abdillâh b. Ahmed b. Alî el-Hasenî es-Semhûdî, Vefâ' ü'l-vefâ bi-ahbâri dâri'lMudtafâ (Beyrut: Daru'1-Kutubi'l-İlmiyye, 1419/1987), 4/128.

8 Ebu'l-Fida İsmail b. Ömer b. Kesîr İbn Kesîr, el-Bidâye ve'n-nihâye (Beyrut: Mektebetu'1-Maârif, 1990), 5/335-336.

9 M. A. Mannan, İslâm Ekonomisi Teori ve Pratik, 163. Mesela Benî Nadîr topraklarının bir kısmı Hz. Ebû Bekir, Abdurrahman b. Avf, Zübeyr b. Avvâm, Ebû Dücâne Simak b. Hareşe es-Sâidi ve benzeri kişilere iktâ olarak verilmiştir. Ahmed b. Yahya b. Câbir b. Davud el-Belâzurî, Fütûhu'l-büldân (Beyrut: Mektebetü'l-Meârif, 1987), 28,31. Bir başka Yahudi kabilesi olan Benî Kurayza, Hendek Savaşı'nda müşriklerle anlaşarak Müslümanlara ihanet etmiş ve kendilerine gereken ceza verildikten sonra malları Müslümanlara dağıtılmıştır. Ebû Abdullah Muhammed b. İsmail el- Buhârî, el-Câmi 'u's-sahîh (Beyrut: Dâru İbn Kesîr, 2003), "Meğazî", 14. Aynı şekilde Vâdilkurâ arazilerinin bir bölümü Benî Uzre kabilesinin başkanı ve aynı zamanda Hicaz halkından Allah Resulü'ne kabilesinin zekâtını getiren ilk kişi olarak bilinen Hamza b. Numan b. Hevze'ye iktâ olarak verilmiştir. Belâzurî, Fütûhu'l-büldân, 48; Muhammed Hamidullah, İslam Peygamberi: (Hayatı ve Faaliyeti), çev. Salih Tuğ (İstanbul: İmaj Yayınevi, 2003), 1/597. Bazı kaynaklarda Hamza yerine Cemra b. Nu'man geçmektedir. Bk. Ebu'lFadl Ahmed b. Ali b. Muhammed b. Ahmed b. Hacer el-Askalânî, el-İsâbe fi temyizi's-sahabe (Beyrut: Daru'lKutubi'l-İlmiyye, 1415), 3/61. Öte yandan Hadramut bölgesinde bir toprak parçası Vâil el-Hadramî'ye vermiştir. Belâzurî, Fütûhu'l-büldân, 99. Hadramut, Hadramevt olarak da telaffuz edilmektedir. Arabistan yarımadasında, Yemen'in güney ve güneydoğusunda yer alan coğrafi bir bölgedir. Bk. Ebu Abdullah b. Abdillah el-Hamevî Yakut, Mu'cemü'l-buldân (Beyrut: Dâru's-Sadr, 1977), 2/269-270.; Hüseyin Algül, "Hadramut", Türkiye Diyanet Vakfi İslam Ansiklopedisi (Erişim 07 Temmuz 2020). Yemâme'de bulunan bir arazi de Furât b. Hayyân el-Acli'ye iktâ olarak verilmiştir. Ebû Ubeyd, Kitâbü'l-emvâl, 368; Ebû Ahmed Humeyd b. Mahled b. Kuteybe el-Horasânî İbn Zenceveyh, Kitâbu'l-emval, thk. Şâkir Zîb Feyyâz (Riyad, 1986), 614; Belâzurî, Fütûhu'l-büldân, 21; Muhamed Hamidullah, Allah Resulü tarafından Furât bin Hayyân'a hem Yemâme hem de Bahreyn'de toprak verdiğini ifade eder. Bk. el-Vesâiku's-siyâsiyye, çev. Vecdi Akyüz (İstanbul: Kitabevi, 1997), 30.

10 Ebû Yusuf, Kitabü'l-harâc, 62; Muhammad Hamidullah, el-Vesâiku's-siyâsiyye, 173, 187,190.

11 İrfan Mahmut Rânâ, Hz. Ömer Döneminde Ekonomik Yapı, çev. Ahmet Koç (İstanbul: Bir Yayıncılık, 1985), 39-40; Demirci, "İkta"; Mehmet Nadir Özdemir, Hz. Peygamber Döneminde Ganimet Uygulamaları (Ankara: Otto Yayınları, 2016), 2016.

12 Ebû Ubeyd, Kitâbü'l-emvâl, 367; Ebû Ahmed Humeyd b. Mahled b. Kuteybe el-Horasânî, Kitâbu'l-emval, thk. Şâkir Zîb Feyyâz (Riyad, 1986), 607. Bazı kaynaklarda Allah Resulü'nün Zübeyr'e iktâ ettiği arazinin Hayber' de hurma ve meyve ağaçlarıyla dolu Cürf adında ve iki üç fersah uzunluğunda bir yer olduğu aktarılmıştır. Ebû Ubeyd, Kitâbü'l-emvâl, 368, 372; Ebû Yusuf, Kitabü'l-harâc, 61; İbn Zenceveyh, Kitâbu'l-emval, 614; Semhûdî, Vefâ' '̈̈l-vefâ 
Hz. Peygamber'in arazilerin dışında evi olmayanlara ev veya evin yapılabileceği uygun bir toprak parçasını iktâ ettiği bilinmektedir. Nitekim Erkam b. Ebi'l-Erkam’a hicretten sonra Medine'de bir ev vermiştir. ${ }^{13}$ Hâlid b. Velîd, evin darlığından şikâyet edince Allah Resulü, kendisine evinin yakınında bir yer vermiştir. ${ }^{14}$ Abbâs b. Abdulmuttalib'e de aynı gerekçeyle bir ev iktâ etmiştir. ${ }^{15}$ Allah Resulü, bunların dışında zaman zaman bazı kuyuları da iktâ olarak vermiştir. ${ }^{16}$

Allah Resul'ünün verdiği iktâların bir kısmının amacı, insanların kalplerini İslâm'a 1sındırmak, ${ }^{17}$ Müslümanlar için tehlikeli olabilecek kişilerin şerlerini defederek zararsız hale getirmektir. ${ }^{18}$ Öte yandan kabile reislerinin desteğini almak amacıyla henüz fethedilmemiş yerlerden gelenlere arazi vererek, bölgelerin fethini teşvik etmek ve buraların Müslümanların eline geçmesini kolaylaştırmaktır. ${ }^{19}$

Hz. Peygamber, bölgelerin fethini kolaylaştırmak ve Müslümanları cihada teşvik etmek amacıyla da arazileri iktâ etmiştir. Bu amaçla verilen araziler, henüz Müslümanların eline bulunmayan ancak bazı kişilerin istekleri doğrultusunda kendilerine verilen topraklardı.

bi-ahbâri dâri'l-Mudtafâ, 3/67. Zübeyr b. Avvam ile evli olan Esma bt. Ebî Bekir, Hz. Peygamber'in Zübeyr'e verdiği araziden hurma çekirdeklerini taşıdığını ifade etmektedir. Bk. Buhârî, “Humus”, 19; Muhammed b. Sa'd b. Menî ez-Zührî İbn Sa'd, Kitâbü't-tabakâti'l-kebîr (Kahire: Mektebetü'l-Hâncî, 2001), 10/238. Bu iki toprak parçasının aynı arazi mi yoksa farklı iki arazi mi olduğu hakkında net bir bilgi olmamakla birlikte aynı arazi olduğu anlaşılmaktadır. Zira muhacirlerin birçoğunun arazilere ihtiyaç duyduğu bir dönemde Zübeyr b. Avvâm'a iki ayrı arazinin iktâ edildiği düşünülemez. Öte yandan Hz. Peygamber'in Salit'ten araziyi alıp Zübeyr'e vermesi de verilen arazinin mülkiyetinin tamamen Hz. Peygamber'in yönetiminde olduğunun göstergesidir.

13 İbn Hacer, el-İsâbe fi temyizi's-sahabe, 1415), 1/198.

14 İbn Sa'd, Kitâbü't-tabakâti'l-kebîr, 4/252; Muhammad Hamidullah, el-Vesâiku's-siyâsiyye, 33; Allah Resulü'nün Hâlid'e verdiği iktâ hakkında detaylar için bk. Mustafa Fayda, Allah'ın Kılıcı Halid b. Velid (İstanbul: İFAV Yayınları, 2016), 133.

15 İbn Sa'd, Kitâbü't-tabakâti'l-kebîr, 4/18.

16 Rivayet edildiğine göre el-Abbâs es-Sülemî Hz. Peygamber'den Cened ve Aden arasında bulunan Desîne bölgesinde bulunan açık bir kuyuyu kendisine vermesini istedi. Allah Resulü de yolcuların su ihtiyacını engellememek ve onlardan arta kalan suyu kullanmak koşuluyla söz konusu kuyuyu kendisine verdi ve bunu da belgelendirdi. Bk. İbn Sa'd, Kitâbü't-tabakâti'l-kebîr, 9/75.

17 Ebû Yusuf, Kitabü'l-harâc, 62.; Muhammad Hamidullah, el-Vesâiku's-siyâsiyye, 173, 187,190.

18 M. A. Mannan, İslâm Ekonomisi Teori ve Pratik, 172.

19 Mustafa Demirci, İslâm'ın İlk Üç Asrında Toprak Sistemi (İstanbul: Kitabevi), 229. Allah Resulü, bu sebeple hicretin yedinci yılında İslâmiyet'e davet amacıyla çeşitli yerlere mektuplar gönderdi. Bunlar içerisinde Yemâme halkı da vardı. Allah Resulü'nün davet mektubunu alan Yemâmeliler, Medine'ye bir heyet gönderdiler. Bu heyet içerisinde bulunan Müccâ'a b. Mürare, Allah Resulü'nden ölü bir araziyi kendisine iktâ olarak vermesini istedi. Allah Resulü de Yemâme'de bulunan bir araziyi kendisine iktâ etti ve belgelendirmek için de bir vesika verdi. Vesikanın içeriği hakkında bk. Ebû Ubeyd, Kitâbü'l-emvâl, 373; İbn Zenceveyh, Kitâbu'l-emval, 614; Belâzurî, Fütûhu'l-büldân, 118-119. Aynı şekilde Medine'ye gelen Âmir b. Sa'saa kabilesine mensup bazı kişilere bölgelerinde su kenarında bulunan bazı yerleri iktâ etti. Bunu teyit için de onlara yazılı bir vesika verdi. Söz konusu vesika, sonraki nesillere intikal etti. İbn Sa'd, Kitâbü't-tabakâti'l-kebîr, 9/50. Verilen bu belgeler, bir çeşit tapu senedi konumundayd. 
Mesela Hz. Peygamber, Abdurrahman b. Avf'a Şam bölgesi fethedildiği takdirde es-Selil denen bölgeyi kendisine iktâ edeceğini bildirmiştir. ${ }^{20}$

Hz. Peygamber, bütün Müslümanların istifade edebileceği yerleri belirli bir şahsa iktâ olarak vermekten kaçınmıştır. Zira umumun menfaati, kişinin menfaatinden önce gelmekteydi. Nitekim Hz. Peygamber, Ebyad b. Hammal'a Ma'rib’ deki tuz ocağını iktâ olarak vermiş ancak kendisine "burası su pınarı gibidir" denince mezkûr yeri iktâ olarak vermekten vazgeçerek başka bir yer vermiştir. ${ }^{21}$

Netice itibariyle Hz. Peygamber, farklı kişilere çeşitli yollarla birçok araziyi iktâ olarak vermiştir. Muhammed Hamidullah, Hz. Peygamber'in verdiği iktâlarla ilgili bilgi ve belgeleri toplamış ve "el-Vesâiku's-siyâsiyye" adlı eserinde neşretmiştir. ${ }^{22}$

Tarih boyunca iktâ ile ilgili pek çok çalışma yapılmasına rağmen Râşid Halifeler Dönemi'yle ilgili müstakil bir çalışmaya rastlayamadık. “İslâm'ın İlk Üç Asrında Toprak Sistemi”"23 ve "Hulefa-yi Raşidin Dönemi'nde Tarım”24 gibi çalışmalar yapılmış ancak iktâ konusu müstakil olarak ele alınmamıştır. Zaman zaman tartışmalara da konu olan iktâ kavramı, ilk dönem kaynakları esas alınarak ve yeri geldiğinde muahhar eserlerden de istifade edilerek izah edilmeye çalışılmış ve okuyucuların istifadesine sunulmuştur. Ayrıca halifelerin savâfî ve ölü topraklar üzerindeki tasarrufları da değerlendirilmiştir.

\section{1. İktânın Sözlük ve Terim Anlamları}

Sözlükte "ayırmak, kesmek,,25 mülkiyet, faydalanma ve bağışlama"26 gibi anlamlara gelen iktâ, devlet başkanının veya onun yetki verdiği birinin hazinenin mülkü olan bir topră̆ı, maden ocağı veya buna benzer tabii kaynakların mülkiyeti ile bir şahsa vermesi veya

20 Muhammad Hamidullah, el-Vesâiku's-siyâsiyye, 31. Aynı şekilde Ebû S'alebe el-Haşnâ adındaki bir sahabiye o esnada Rumların elinde bulunan bir araziyi iktâ etmiş ve bunu belgelemiştir. Ebû Ubeyd, Kitâbü'l-emvâl, 368.; İbn Zenceveyh, Kitâbu'l-emval, 614.

21 Belâzurî, Fütûhu'l-büldân, 99.; Muhammad Hamidullah, el-Vesâiku's-siyâsiyye, 30. Zira Hz. Peygamber, buranın mevât bir toprak olduğunu ve Ebyad'ın burayı ihyâ ve imar edeceğini düşünmüştür. Ancak kuyu ve kaynak suları gibi herkesin istifade edebileceği bir maden olduğunu öğrenince iktâ olarak vermekten vazgeçmiştir. Çünkü onun sünneti gereği bütün insanlar ateş, su ve merada ortaktırlar. Bunları bir kişiye tahsis etmek doğru değildi. Ebû Ubeyd, Kitâbü'l-emvâl, 374.

22 Muhammad Hamidullah, el-Vesâiku's-siyâsiyye, 173 vd.

23 Mustafa Demirci, İslâm'ın İlk Üç Asrında Toprak Sistemi (İstanbul: Kitabevi).

${ }^{24}$ Fatih Oğuzay, Hulefâ-i Râşidîn Döneminde Tarım Kültürü, (İstanbul: Marmara Üniversitesi, Sosyal Bilimler Enstitüsü, Doktora Tezi, 2016).

25 Ahmed Muhtâr Abdulhamid Ömer, Mu'cemu'l-lugati'l-Arabiyyeti'l-Muâstra (Alemu'l-Kutub, 2008), 1869.; Rânâ, Hz. Ömer Döneminde Ekonomik Yapı, 39; Mustafa Demirci, "İkta”, Türkiye Diyanet Vakfı İslâm Ansiklopedisi (Erişim 24 Nisan 2020);Mușțafá Sibā‘ī, İslam Sosyalizmi, çev. Yaşar Nuri Öztürk (İstanbul: Yeni Boyut, 2010), 185.

${ }^{26}$ Nezih Hammâd, Mu'cemu'l-mustalehâti'l-mâliyyeti ve'l-iktisâdiyyeti fi'l-luğati'l-fukahâ (Dımeşk,: Dâru'l-Kalem, 2008), 75; M. A. Mannan, İslâm Ekonomisi Teori ve Pratik, 172. 
mülkiyeti devlete kalmak şartıyla faydalanma ve kullanma hakkını bağışlaması ${ }^{27}$ anlamında kullanılan bir terimdir. Aynı şekilde kamunun tasarrufunda bulunan bir arazinin veya taşınmaz malların mülkiyetini, işletme veya faydalanma hakkını, belirli şahıslara tahsis edilme şeklinde de ifade edilmiştir. ${ }^{28}$

Devlet hazinesine ait olan her arazi, iktâ olarak verilmemiştir. İktâ olarak verilen araziler, genel olarak mevât araziler ile savâfi topraklarıdır. Halifelerin bireylere mülk olarak verdikleri araziler, daha önce işlenmemiş âtıl arazilerdir. Dolayısıyla araziyi işleyerek zirai üretimi sağlayacak kimselere veriliyordu. Temlik olarak değil de faydalandırma ve vergi almak amacıyla verilen araziler ise ileride açıklanacağı gibi daha çok savâfî arazilerdir. Çünkü bunlar daha önce işlenmiş ma'mur arazilerdi.

Bir arazinin iktâ edilebilmesi için mutlaka hazineye ait olması gerekiyordu. Herhangi bir dine veya etnik unsura bakılmaksızın özel mülkiyet kapsamında olan topraklar iktâ edilmezdi. Allah Resulü, sahibi belli olan bir araziyi ihyâ edip hurma diken şahsa, toprağı eski sahibine teslim etmesini emrederek hurma ağaçlarını da çıkarıp götürmesine hükmetti. Böylece Hz. Peygamber, âtıl da olsa sahibi belli olan arazileri, bir başkası tarafından ihyâ edilmesine izin vermedi. Zira herhangi bir kimse, başkasına ait olan bir araziye ağaç dikip ona sahip olamazdı. ${ }^{29}$ Çünkü Allah Resulü, sahipleri bulunmayan toprakların mülkiyetinin Allah'a, onun Resulüne ve bütün Müslümanlara ait olduğunu ifade etmiştir. ${ }^{30} \mathrm{~Hz}$. Ömer de bu tür toprakların mülkiyetinin devlete ait olduğunu bildirmiştir. ${ }^{31}$

Raşid Halifeler Dönemi'nde aynı uygulamanın devam ettiği bilinmektedir. Nitekim Hz. Ömer, Irak valisi Sa'd b. Ebî Vakkas'a haber göndererek Saîd b. Zeyd'e bir toprak parçasını vermesi talimatında bulundu. Sa'd da ona Rufeyloğullarına ait bir araziyi verdi. Bunun üzerine İbn Rufeyl, bu durumdan rahatsız oldu. Mağduriyetini gidermek amacıyla Halife Ömer'in yanana giderek cizye karşılığında canı, evlatları ve mallarının garantide olması gerektiğini hatırlattı ve kendisine ait bir arazinin Saîd'e verildiğini bildirdi. Bunun üzerine halife, Sa' d'a haber göndererek İbn Rufeyl'in arazisini kendisine geri vermesini istedi. Böylece

\footnotetext{
27 Celâluddîn Abdurrahmân b. Ebî Bekir es-Suyûtî Suyûtî, Mu'cem mekâlîdi'l-ulum fi'l-uudud ve'r-rusûm, thk. Muhammed İbrahim (Kâhire: Mektebetu'l-Âdâb, 2004), 161; Muhammed Revvâs Kal'ac'1, Mu'cemu lugati'lfukahâ (Dâru'n-Nefâis, 1988), 84; İbrahim Muhammed, en-Nuzumu'l-maliyye fi'l-İslâm (Kâhire,: el-Hey'etü'lMısriyyeti'l- Âmme li'l-Kitâb, 1986), 100; Celal Yeniçeri, İslâm İktisadının Esasları (İstanbul: Şamil Yayınevi, 1980), 47; Demirci, "İktâ".

28 Rânâ, Hz. Ömer Döneminde Ekonomik Yapı, 39; Demirci, "İktâ".

29 Ebû Dâvûd, "Kitabü'l-Harâc", 35-37.

30 Ebû Ubeyd, Kitâbü'l-emvâl, 367.

31 Ebû Ubeyd, Kitâbü'l-emvâl, 371.
} 
Halife Ömer, İbn Rüfeyl'in mağduriyetini gidermekle birlikte gönlünü almak için de hazineden maddi destekte bulundu. ${ }^{32}$ Netice itibariyle Hz. Osman'ın dediği gibi bir arazinin iktâ olarak verilebilmesi için o arazinin herhangi birinin mülkünde olmaması gerekmektedir. ${ }^{33}$

\section{2. İktâ Olarak Verilen Araziler}

\subsection{Savâfî Araziler}

Sözlükte "ayırma, seçme ve saflaştırma" anlamlarına gelen savâfî, ${ }^{34}$ çeşitli nedenlerden dolayı ortada kalan ve sahibi bulunmayan araziler için kullanılan bir terimdir. İhmal edilmiş, sahipleri ölen ve mirasçıları belli olmayan araziler de savâfi olarak kabul edilmiştir. ${ }^{35} \mathrm{Kamu}$ malı olarak kabul edilen bu arazilerin tasarruf yetkisi halifelere aittir. ${ }^{36} \mathrm{Bu}$ tür topraklar, belirli bir vergi karşılığında bazı kişilere verilmiş ${ }^{37}$ ve alınan vergiler halkın menfaati doğrultusunda harcanmıştır. ${ }^{38}$

Râşid Halifeler Dönemi'nde Irak, Suriye ve Misır bölgeleri Müslümanların eline geçince buralarda sahipleri belli olmayan bazı araziler de vardı. Hz. Ömer, bu tür arazilerin hepsini hazine malı olarak kabul etmiştir. ${ }^{39}$ Kaynaklarda geçen bu araziler şu şekilde sıralanmıştır: Savaşta öldürülen ve kaçanların arazileri, Kisra ve yakınlarına ait araziler, ortak meralar, suyun kenarında bulunan araziler, manastırlara ait bazı topraklar ve ormanlık araziler. $^{40}$

Büyük kentlerin çevresindeki verimli alanlarda bulunan ve daha önce hanedan mensuplarına ait olan bu tür topraklar, Halife Ömer tarafından özel bir statüye kavuşturmuştur. Sahibi bulunmayan araziler ise halka gelir getirmesi amaciyla hazineye

32 Yahya b. Âdem, Kitâbü'l-harâc (Kahire: Darü'l-Şuruk, 1987), 96-97.

33 Ebû Ubeyd, Kitâbü'l-emvâl, 376.

34 Ebü'l-Fazl Cemâlüddîn Muhammed b. Mükerrem b. Alî b. Ahmed el-Ensârî er-Rüveyfiî İbn Manzûr, Lisânü'l'Arab (Beyrut: Daru'l-Sadir, 1414), 14/463; Demirci, İslâm'ın İlk Üç Asrında Toprak Sistemi, 85.

35 Ebu'l-Hasen Ali b. Muhammed b. Habîb el-Mâverdî, el-Ahkâmü's-sultaniyye (Kahire: Darü'l-Hadis, 2006), 289; Nezih Hammâd, Mu'cemu'l-mustalehâti'l-mâliyyeti ve'l-iktisâdiyyeti fi'l-luğati'l-fukahâ, 284.

36 Ebû Ubeyd, Kitâbü'l-emvâl, 375; Muhammed Bakır es-Sadr Sadr, İktisâdunâ (el-Mecmeu'l-İlmiyye, 1408), 468; Mustafa Demirci, "Savâfî", Türkiye Diyanet Vakfi İslam Ansiklopedisi (Erişim 07 Mayıs 2020); Hüseyin Algül, İslâm Tarihi Hulefâi Râşidîn (Bursa: Emin Yayınları, 2018), 3/201.

37 Ira M. Lapıdus, İslâm Toplumları Tarihi, çev. Yasin Aktay (İstanbul: İletişim Yayınları, 2005), 125.

38 Mâverdî, el-Ahkâmü's-sultaniyye, 289.

39 Ebû Ubeyd, Kitâbü'l-emvâl, 132; Gâlib b. Abdulkâfî Kureyşî, Evveliyâtu'l-fâruk fi'l-idâreti ve'l-kadâ (Beyrut: Müessesetu'1- Kutubi's-Sekâfiyye, 1990), 151.

40 Ebû Yusuf, Kitabü'l-harâc, 57; Ebû Ubeyd, Kitâbü'l-emvâl, 375; Yahya b. Âdem, Kitâbü'l-harâc, 100; Belâzurî, Fütûhu'l-büldân, 381. Muhammed Ziyâüddîn Reyyis, el-Harâc ve't-tanzimü'l-mâliyye fi'd-devleti'l-İslâmiyye (Kahire: Dâru'l-Meârif, 1969), 156-158; Muhammed Hamidullah, İslam'da Devlet İdaresi, çev. Hamdi Aktaş (İstanbul: Beyan Yayınları, 2016), 308. Bu arazilerin on çeşit olduğunu söyleyenler de vardır. Bk. Belâzurî, Fütûhu'l-büldân, 380 . 
devredilmiştir. Savâfi'l-esfâr denilen bu araziler için divan kurulmuştur. Divanda mülkiyetleri hazineye ait olmak koşuluyla satışına izin verilmemiş ve gelirleri Müslümanlar arasında pay edilmiştir. Hz. Ömer'in halifeliği döneminde bunların yıllık geliri belirli bir meblağa ulaşmış ve bu gelirler halka önemli bir kazanç oluşturmuştur. ${ }^{41} \mathrm{~Hz}$. Osman'ın halifeliğinin ilk zamanlarında ekonomik seviye alabildiğine üst seviyeye çıkmışs2 ve bu meblağ daha da artmıştır. 43

\subsection{Mevât Araziler}

İktâ olarak verilen arazilerden biri de mevât arazileridir. Bu arazi genel olarak yerleşim ve üretim gibi bir amaçla kullanılmayan aynı zamanda herhangi bir şahsın malı olmayan metruk ve verimsiz topraklardır. ${ }^{44}$ Ayrıca bataklık, suyun ulaşmadığı ve tarıma elverişli olmayan araziler de mevât araziler kategorisinde değerlendirilmiştir. ${ }^{45}$ Öte yandan herhangi bir ziraat emaresi bulunmayan yerler de mevât arazisi olarak kabul edilmiştir. ${ }^{46}$ Nitekim Basra, Yemâme ve Yemen bölgesinde bulunan toprakların bir kısmı, ölü topraklar olarak kabul edilmiş, yöneticiler bu tür toprakları halkın istifadesine sunmuşlardır. ${ }^{47}$ Çünkü bu şekilde arazileri iktâ etmeyi Müslümanlar için fayda, düşman için de zarar görmüşlerdir. 48

Allah Resulü, Dûmetu'l-Cendel halkına gönderdiği haberde suyu az olan, ekilip dikilmeyen ve kime ait olduğu bilinmeyen arazilerin tümünün Müslümanların ortak malı olduğunu belirtmiş ve bu tür arazileri mevât statüsünde değerlendirmiştir. ${ }^{49}$

Mevât arazileri belli bir emek harcama sonucu faydalanılacak bir hale getirmek ise onu ihyâ etmek demektir. ${ }^{50}$ Bir başka ifadeyle ihyâ, ölü bir araziyi imar etmek, kullanılabilir ve maksada uygun bir hale getirmektir. ${ }^{51}$ Ölü bir toprağın etrafını diken, taş, ağaç dalları ile çevirmek, dikenlerini temizlemek, otlarını yolmak, kuyu kazmak, oraya su götürmek veya

41 Ebû Yusuf, Kitabü'l-harâc, 57. Emeviler döneminde yaşanan Cemacim olayında halk, divan defterlerini yakmış ve her kabile kendisine yakın olan bu toprakları almıştır. Bk. Belâzurî, Fütûhu'l-büldân, 381; Demirci, "Savâfî".

42 Abdulaziz b. İbrahim el-Ömerî, el-Vilayetu ala'l-buldan fi asri'l-hulafâi'r-raşidîn (Riyad: Dâru İşbiliyâ, 2001), 443; Ali Muhammed Sallabi, II. Halife Hz. Ömer'in Hayatı, Şahsiyeti ve Dönemi, çev. Mehmet Akbaş (İstanbul: Ravza Yayınları, 2008), 333-334.

43 Belâzurî, Fütûhu'l-büldân, 187; Demirci, “İkta”.

44 Hamza Aktan, "ihyâ", Türkiye Diyanet Vakfı İslam Ansiklopedisi (Erişim 09 Mayıs 2020).

45 Muhammed Ebu Zehra Ebu Zehra, İslam'da Sosyal Dayanışma, çev. Ethem Ruhi Fığlalı-Osman Eskicioğlu (İstanbul: Yağmur Yayınları, 1976), 89.

46 Ebû Yusuf, Kitabü'l-harâc, 63.

47 Ebû Ubeyd, Kitâbü'l-emvâl, 614.

48 Ebû Yusuf, Kitabü'l-harâc, 62; Selim A. Sıddıkî, İslam Devletinde Mali Yapı, çev. Rasim Özdenören (İstanbul: Fikir Yayınları, 1968), 96.

49 Belâzurî, Fütûhu'l-büldân, 82.

50 Aktan, "ihyâ".

51 Yeniçeri, İslâm İktisadının Esasları, 51. 
oradan su çıkarmak, o arazileri ihyâ etmek anlamına gelmektedir. ${ }^{52}$ Ancak bu toprağın daha önce herhangi bir kişinin elinde olup tarıma elverişli bir hale gelmemesi ve aynı zamanda ekilip biçilen bir yerin olmaması gerekir. ${ }^{53}$

Mevât arazileri diriltmekten maksat, topraksız halkı toprak sahibi yapmak, toprağ ıslah edip ekimini temin etmek, arazisi olanları da üretime teşvik etmekti. Böylece hazineye ait olan araziler, belirli kişilere iktâ edilirken, özellikle sahipsiz toprakların işlenerek mülk haline dönüştürülmesi özendirilmiştir. ${ }^{54} \mathrm{Bu}$ sayede hem bireyler bir geçim aracı elde etmiş hem de vergi alındığı için devlet ma' mur edilmiştir. Bu mülkiyet, iktâ şartları yerine getirildiği müddetçe geçerliydi yoksa nihai bir mülk edinme değildi. Çünkü iktâ, ölü toprakları işleme üzerinden bireye bazı haklar vermekle birlikte sürekli mülk edinme yetkisi vermemiştir. ${ }^{55}$

Hz. Ali'nin halifeliği zamanında ölü topraklar ihyâ edilmiştir. Zira Hz. Ali, insanları bu tür toprakları ihyâ etmeye teşvik ettiği gibi destek de olmuştur. Rivayet edildiğine göre adamın biri Hz. Ali’ye gelerek, sahipleri tarafından terk edilmiş çorak bir araziye arık kazarak su götürdügünü ve bu vesileyle toprağı ziraata kazandırdığını ifade etmiştir. Hz. Ali de kendisine, "Sen ıslah edici ve yeşerticisin." demiş ve araziyi ondan almayarak yaptığı işi desteklemiştir. ${ }^{56}$

\section{3. İskân Amacıyla verilen İktâlar}

Allah Resul'ünün halka verdiği iktâların büyük çoğunluğu iskân amaçlı olduğu ifade edildi. Ondan sonra Müslümanların idaresini üstlenen Hz. Ebû Bekir'in halifeliği döneminde de aynı uygulama devam etmiştir. Ancak Hz. Ebû Bekir'in halifeliği döneminde iktâ örnekleri son derece sınırlıydı. Çünkü bu dönemde genellikle ridde olaylarının yaşanması, Hire ${ }^{57}$ ve Enbar $^{58}$ gibi bazı yerlerin dişında ciddi manada fetihlerin gerçekleşmemesi ve buna bağlı olarak yeni arazilerin Müslümanların eline geçmemesi gibi nedenlerle Hz. Peygamber dönemindeki yapı aynen korunmuştur.

\footnotetext{
52 Yahya b. Âdem, Kitâbü'l-harâc, 121; Ebû Dâvûd Süleyman b. Eş'as es-Sicistâni el-Ezdî, Sünenu Ebî Dâvud (Beyrut: Dâru'r-Risâletu'l-Âlemiye, 2009), "Kitâbü'l-Harâc", 35-37; Aktan, "ihyâ".

53 Yahya b. Âdem, Kitâbü'l-harâc, 121.

${ }^{54}$ Ira M. Lapıdus, İslâm Toplumları Tarihi, 124; Cengiz Kallek, Asr-ı Saâdet'te Yönetim-Piyasa İlişkisi (İstanbul: İz Yayıncilık, 1997), 108-109.

55 Sadr, İktisâdunâ, 467, 511; Muhammad Hamidullah, el-Vesâiku's-siyâsiyye, 293-295.

56 Yahya b. Âdem, Kitâbü'l-harâc, 99.

57 İslamiyet'ten önce Lahmiler'in başkenti olan Hire, bugün Irak'ta bulunan Necef'in bir ilçesidir. Kûfe'nin 5 km. güneydoğusunda yer almaktadır. Yakut, Mu'cemü'l-buldân, 1/328-330; Hüseyin Ali ed-Dakûkî, "Hire", Türkiye Diynet Vakfi İslâm Ansiklopedisi, (Erişim 09 Temmuz 2020).

58 Irak'ta Fırat Nehri'nin kenarında harabeleri bulunan tarihî bir şehir. Yakut, Mu'cemü'l-buldân, 1/258; Abdulazîz Dûrî, “Enbâr”, Türkiye Diynet Vakfı İslâm Ansiklopedisi (Erişim 09 Temmuz 2020).
} 
Bütün bu nedenlerle birlikte yine de bazı iktâ örneklerine rastlamak mümkündür. Mesela halifenin Yemen'de bulunan Hadrame köyünün arazinin bir kısmını Müccâ'a b. Mürâre el-Hanef'ye, ${ }^{59}$ Kanât ile Cürf arasındaki mevât bir araziyi de Zübeyr b. Avvam'a iktâ olarak verdiği rivayet edilmektedir. ${ }^{60}$ Abdullah b. Zübeyr, halifeden Medine'deki Sel' Dağı'nı iktâ olarak almış ve üzerine iki köprü yaptırmıştır. ${ }^{61}$

İskân amaciyla halka en fazla toprak tahsis edenlerden biri Hz. Ömer'dir. O, fethedilen yeni yerlerde bulunan halkın Müslümanlarla tanışması ve İslâm'ın insanlar arasında kalıcı hale gelebilmesi için Müslümanları bu yeni yerlere gönderip iskân etmeye teşvik etmiştir. Nitekim Şam bölgesi fethedildiğinde oranın vali ve komutanlarına haber göndererek herhangi birinin mülkü olmayan ölü toprakları iskân amacıyla halka vermeleri talimatında bulunmuştur. ${ }^{62}$ Ayrıca Cezire bölgesi Müslümanların eline geçince burada yaşayan yerel halkın bir kısmı, memleketlerini bırakıp gitmişlerdi. Böylece Re'su'l-Ayn ve çevresinde bulunan metruk yerler, halifenin talimatı doğrultusunda Müslüman halka iktâ olarak verilmiştir. ${ }^{63}$

Hz. Ömer döneminde İslâm coğrafyası alabildiğine genişlemiş ve Sasani imparatorluğunun bütün toprakları ele geçirilmişti. Dolayısıyla Sevad arazilerinin tamamı artık Müslümanlarındı. Bu toprakları başkent Medine' den idare etmek zorlaşmıştı. Bunun için yeni şehirlerin kurulması kaçınılmaz hale gelmişti. Bu amaçla Halife Ömer, Irak genel komutanı Sa'd b. Ebî Vakkas'a mücahitler için uygun bir yer bulması gerektiğini bildirmişti. Kurulacak şehirde her bir kabile için ayrı bir mahalle tahsis edilmesi ve bu yerin onlara iktâ olarak verilmesi talimatında bulunmuştu. Böylece Sa'd, uzun uğraşlar sonucunda Kûfe'de bir şehir inşa etmiştir. Mescid, hükümet konağı ve hastane başta olmak üzere Fezâre, Temîm, Tay, Esed, Bekir, Becîle ve Hemdan gibi kabile mensuplarının her birinin yerleşeceği yeri, hazine topraklarından tedarik etmiştir. Öte yandan insanların oturabilecekleri uygun bir ev ve geçimlerini temin etmeleri için Zübeyr b. Avvâm, Talha b. Ubeydullah, Abdullah b. Mes'ûd, Habbâb b. Eret, Ebû Mûsâ el-Eş'arî, Hâşim b. Utbe b. Ebî Vakkas, Huzeyfe b. el-Yemân, Amr b. Hureys, Adî b. Hâtim et-Tâî, Cubeyr b. Mu'tim ve Cerîr b. Abdullah gibi sahâbîlerin de

\footnotetext{
59 Ebû Ubeyd, Kitâbü'l-emvâl, 368, 373-374; Belâzurî, Fütûhu'l-büldân, 126-127; Ekrem Ziyâ el-Ömerî, Asru'l-hilâfeti'rraşide (Riyad: Mektebetu'l-Ubeykân, 2009), 241; Demirci, “İkta”.

60 Yahya b. Âdem, Kitâbü'l-harâc, 111; Belâzurî, Fütûhu'l-büldân, 31; Semhûdî, Vefâ' '̈̈l-vefâ bi-ahbâri dâri'l-Mudtafâ, 4/49; Ekrem Ziyâ el-Ömerî, Asru'l-hilâfeti'r-raşide, 240-241.

61 Cengiz Kallek, Asr-ı Saâdet'te Yönetim-Piyasa İlişkisi, 242.

62 Belâzurî, Fütûhu'l-büldân, 207; İbn Hacer, el-İsâbe fi temyizi's-sahabe, 2/145.

63 Belâzurî, Fütûhu'l-büldân, 243.
} 
bulunduğu birçok kişiye iktâ yoluyla arazi vermiştir. Daha sonra buraya gelip yerleşenlere de aynı metotla arazi verilmeye devam edilmiştir. ${ }^{64} \mathrm{Bu}$ uygulamadan yola çıkarak Hz. Ömer'in halifeliği döneminde askeri üs olarak kurulan diğer şehirlerin de aynı yollarla kurulduğu söylenebilir.

Halife Ömer, Basra halkının çorak ve rutubetli, otları bitmeyen, bir tarafı çöl diğger tarafı da tuzlu denizin bulunduğu bir mekâna yerleştiklerini, ekilecek arazilerin ve sağılacak hayvanlarının olmadı̆̆ını, ${ }^{65}$ geçim imkânlarının dar ve sayılarının kalabalık olduğunu öğrenince daha önce Kisrâ ailesinin elinde bulunan toprakları onlara iktâ olarak vermiştir. ${ }^{66}$ Hz. Osman da halife olduğunda Basra toprakları içerisinde daha önce imar edilmemiş olan ölü toprakların bir kısmını uygun gördüğü kimselere iskân amacıyla iktâ olarak vermiştir. ${ }^{67}$

Hz. Ömer'in iskân amaciyla iktâ olarak vermesinin bir diğer örneği de Kazvin fethi esnasında olmuştur. Rivayet edildiğine göre Hz. Ömer'in emriyle Kazvin bölgesinin fethiyle görevlendirilen el-Berâ b. Âzib, bölgeyi barış yoluyla fethetmiştir. Oranın halkı, Müslüman olmayı tercih etmiş ve toprakları da öşür arazisi olarak kabul edilmiştir. Berâ, Tuleyha b. Huveylid el-Esedî’nin de aralarında bulunduğu beş yüz civarında Müslümanı buraya yerleştirmiş ve sahipsiz toprakları da onlara iktâ olarak vermiştir. ${ }^{68}$ Öte yandan Azerbaycan Müslümanların eline geçince Kûfe, Basra ve Şam’dan bazı Arap kabileleri getirilip buraya yerleştirilmiş ve kendilerine bazı topraklar verilmiştir. ${ }^{69} \mathrm{Bu}$ şekilde verilen iktâlar sayesinde söz konusu bölgelerde yaşayan halkın Müslümanlaşması sağlanmıştır.

Halifeler, araziler dışında zaman zaman konaklamak amacıyla meskenleri de iktâ olarak vermişlerdir. Nitekim Hz. Osman, valilerinden biri olan ve yolsuzlukları ile gündeme gelen Velid b. Ukbe b. Ebî Muayt'ı yanından uzaklaştırmak istemiş ve onu Basra'ya göndermiştir. Velid, Basra'da maddi değeri fazla olan bir konağı istemiş fakat halifenin emriyle vali, kendisine diğerlerine verilen konaklara benzer bir konak iktâ etmiştir. ${ }^{70}$ Öte yandan Halife Osman, Basra'da Abbas b. Rebîa el-Harîs'e de bir konak vermiştir. ${ }^{71}$

\footnotetext{
64 Ebü'l-Abbâs Ahmed b. Ebî Ya'kūb İshâk b. Ca'fer b. Vehb b. Vâzih el-Ya'kūbî, Kitâbü'l-büldân (Beyrut: Daru'lKutubi'l-İlmiyye, 1422/2001), 147-149; Ebu Ca'fer Muhammed b. Cerîr Taberî, Târîhu'r-rusûl ve'l-mulûk, thk. Muhammed Ebû'l-Fadl İbrahim (Kahire: Dâru'l-Meârif, ts.), 3/589.

65 Belâzurî, Fütûhu'l-büldân, 493, 496-497.

66 İzzuddin Ebü'l Hasan Ali b. Muhammed İbnü'l-Esîr, el-Kâmil fi't-târih, thk. Ömer Abdusselam et-Tedmirî (Beyrut: Dârü'1 Kitâbi'l Arabiyye, 1417/1996), 2/366.

67 Ebû Ubeyd, Kitâbü'l-emvâl, 375-376.

68 Belâzurî, Fütûhu'l-büldân, 449-450.

69 Belâzurî, Fütûhu'l-büldân, 460.

70 Belâzurî, Fütûhu'l-büldân, 491.

71 Belâzurî, Fütûhu'l-büldân, 507.
} 
Halifelerin iskân amacıyla verdikleri iktâların bir kısmı da sınır güvenliğini sağlamaktı. Çünkü buralara yerleştirilen askerlerin toprağa ihtiyaçları vardı. Nitekim Antakya, Müslümanlar tarafından fethedildikten sonra hem Hz. Ömer hem de Hz. Osman buraya büyük bir ehemmiyet vermişlerdi. Bölge fethedildiğinde Hz. Ömer, Ebû Ubeyde b. Cerrah'a Antakya'ya iyi niyetli ve tedbirli Müslümanlardan bazılarını yerleştirmesini, onları savaşa hazır hale getirmesini, atiyyelerini ihmal etmemesini emretti. Ebû Ubeyde'den sonra oraya vali olan Muaviye'ye de aynı talimatta bulundu. Daha sonra Müslümanların idaresini üstlenen Hz. Osman da Muaviye'ye haber gönderip sınırda sürekli asker bulundurmasını ve onlara iktâ yoluyla arazi tahsis etmesini istedi. ${ }^{72}$

Muaviye b. Ebî Süfyan, Halife Osman'ın talimatlarını yerine getirmiş, başta Akka ve Sur olmak üzere Akdeniz kıyısında bulunun şehirlerin kalelerini tamir etmiştir. Daha sonra farkl1 yerlerden askerleri getirip buraya yerleştirmiştir. Muaviye, Şam bölgesindeki sahilleri de iskâna açmıştır. Ayrıca Mısır'da bulunan tersanelerin bir benzerini, dışarıdan getirdiği marangozlar vasıtasıyla Akka ve Ürdün'de de inşa ettirmiştir. ${ }^{73}$ Bunların giderlerini hazineden karşıladığı gibi oraya yerleşenlere de arazi vermiştir. ${ }^{74}$ Böylece harabe halinde olan birçok yerleşim yeri ve kale onarıldığ 1 gibi yeni yerler de inşa edilmiştir. ${ }^{75}$

Hz. Osman'ın güvenlik amacıyla bazı yerleri iktâ olarak vermesiyle alakalı bir başka olay da Kıbrıs fethinden önce yaşanmıştır. Zira rivayet edildiğine göre Muaviye b. Ebî Süfyan, Hz. Ömer'den Kıbrıs'ın fethi için izin istemiş fakat halife kendisine gerekli izni vermemiştir. Daha sonra halife olan Hz. Osman'dan da 1srarla izin isteyince Halife Osman, ona izin vermekle birlikte sahile yeni asker sevk edip boş evlere yerleştirmesini ve onlara iktâ yoluyla toprak vermesini emretmiştir. ${ }^{76}$

Muaviye'nin insanlara arazileri iktâ olarak vermesi sadece bununla münhasır değildir. O Kâlîkalâ'ya (Hasankale/Erzurum) asker gönderdiğinde de buralardaki toprakları askerlere iktâ olarak vermiştir. ${ }^{77}$ Öte yandan Hz. Ömer'in halifeliğinin son, Hz. Osman'ın halifeliğinin ilk döneminde Seydâ, Cübeyl, Beyrut ve Irak'ın bazı yerlerin sahil bölgesi Müslümanların elinden çıkmıştı. Muaviye, bu yerleri düşmanlardan arındırdıktan sonra tamir ederek asker

\footnotetext{
72 Belâzurî, Fütûhu'l-büldân, 201.

73 Belâzurî, Fütûhu'l-büldân, 161.

74 İbnü'l-Esîr, el-Kâmil fi't-târih, 2/280.

75 Celal Yeniçeri, İslam'da Devlet Bütçesi (İstanbul: Şamil Yayınevi, 1984), 340.

76 Belâzurî, Fütûhu'l-büldân, 175.

77 Belâzurî, Fütûhu'l-büldân, 279; Ekrem Ziyâ el-Ömerî, Asru'l-hilâfeti'r-raşide, 245.
} 
yerleştirmiş ve uygun toprakları askerlere iktâ yoluyla vermiştir. ${ }^{78}$ Aynı şekilde sağlam bir kaleye sahip olan Antartûs (Tarsus), Müslümanlar tarafından fethedildiğinde Muaviye, burayı yeniden inşa ederek teşkilatlandırmış ve savaşçlarına araziler iktâ etmiştir. ${ }^{79}$

Muaviye b. Ebî Süfyan, güvenlik gerekçesiyle askerlerine bazı toprakları iktâ olarak verdiği gibi kendisi de zaman zaman halifeden arazi talep etmiştir. Zira Muaviye hem Hz. Ömer hem de Hz. Osman döneminde önemli fetihlerde bulunmuştur. Fethettiği yerlerde iktâ olarak verilecek verimli arazileri görünce bunları değerlendirmiştir. Rivayet edildiğine göre Muaviye, Hz. Osman'dan fethedilen bölgelerde sahipsiz köy ve çiftliklerin bulunduğunu ve bunların haraç arazisine dâhil olmadığını, dolayısıyla bunları kendisine iktâ olarak verilmesini istemiştir. Hz. Osman da Muaviye'nin bu teklifini kabul etmiş, mezkûr çiftlik ve bölgeyi kendisine iktâ olarak vermiştir. Muaviye bunları aldıktan sonra yakınlarına vererek işletmiş, pek çok gelir elde etmiştir. ${ }^{80}$

\section{Gelir Getirmesi Amacıyla Verilen İktâlar}

Halka iktâ olarak verilen arazilerin bir kısmı hazineye gelir getirmiştir. Bu amaçla Hz. Ömer' in savâfî toprakları halka iktâ olarak verdiği ve bunun karşılığında vergi aldığı ile ilgili kaynaklarda bazı bilgiler bulunmaktadır. Nitekim Ebû Yusuf, Medineli yaşlı bazı âlimlerden edindiği bilgiye göre Halife Ömer'in oluşturduğu divan defterlerinde Kisrâ ve yakınlarının arazilerini, savaşta ölen ve kaçanların arazilerini, işlemeye müsait olan mekân ve korulukları, bu işi layıkıyla yapabilecek bazı kişilere çiftlik kurması için tahsis ettiğini bildirmektedir. ${ }^{81} \mathrm{Bu}$ amaçla verilen iktâlar, sicil defterlerine kaydedilmiştir. ${ }^{82}$

Halife Ömer, halka menfaati dokunan girişimci insanlara her zaman değer vermiş ve onların önünü açmak için destek olmuştur. Bunun için onlara boş bulunan bazı arazileri iktâ olarak vermiştir. Bu şekilde hem arazileri değerlendirmiş hem de insanları çalışmaya teşvik etmiştir. Bu maksatla hayvan yetiştirmek amacıyla bazı insanlara özel araziler tahsis etmiştir. ${ }^{83}$ Nitekim rivayet edildiğine göre Basra' da hayvan yetiştiren Ebû Abdillah Nâfi, Basra valisi Ebû Musa el-Eş'ari'ye gelerek Müslümanlardan herhangi birine zararı dokunmayan, haraç arazisi de olmayan Dicle Nehri kenarında uygun bir araziyi hayvan yetiştirmek amacıyla kendisine

\footnotetext{
78 Belâzurî, Fütûhu'l-büldân, 173; İbnü'1-Esîr, el-Kâmil fi't-târih, 2/271.

79 İbnü'l-Esîr, el-Kâmil fi't-târih, 2/323.

80 İbnü'l-Esîr, el-Kâmil fi't-târih, 2/280; Ekrem Ziyâ el-Ömerî, Asru'l-hilâfeti'r-raşide, 245; Corci Zeydan, İslam Uygarlıkları Tarihi, çev. Necdet Gök (İstanbul: İletişim Yayınları, 2012), 1/348.

81 Ebû Yusuf, Kitabü'l-harâc, 57-58.

82 Belâzurî, Fütûhu'l-büldân, 183.

83 Ebû Ubeyd, Kitâbü'l-emvâl, 370.
} 
vermesini istemiştir. Vali Ebû Musa el-Eş'ari de Halife Ömer'den konu hakkında görüş istemiştir. Haberi alan Hz. Ömer, Ebû Musa el-Eş'ari'ye şu talimatta bulunmuştur: "Basra'da at yetiştirilmezken sözü geçen kişi tay yetiştirmek istiyor. Onun için istenilen yer, herhangi birine zararı yoksa hayvan yetiştirmesi ve ekin ekmesi için iktâ edin."84

Hz. Ömer'den sonra halife olan Hz. Osman da hazineye gelir getirmesi amaciyla halka iktâ vermeye devam etmiştir. Hz. Osman, Irak bölgesinde ziraata elverişsiz halde bulunan arazileri mevât statüsünde değerlendirmiş ve ihyâ etmeye çalışmıştır. Çünkü bu şartlardaki toprakların imar edilmesini âtıl kalmasına tercih etmiştir. Bunları ziraata kazandırmanın toplumun menfaati ve Müslümanların çıkarı için daha uygun olacağını düşünmüştür. Zira verilen arazilerden elde edilen gelir sayesinde hazinenin zenginleşeceğini biliyordu. Bu nedenle uygun gördüğü kişilere mevât arazilerinin bir kısmını iktâ olarak vermiştir. ${ }^{85}$

Halife Hz. Osman'ın savâfî toprakları iktâ ederken temlik olarak değil, kira şeklinde vermiştir. Bu şekilde âtıl durumda olan ve verimden düşmüş bulunan yerleri işletmeye verdiğinden üretimde büyük bir yarar sağlamıştır. ${ }^{86}$

Halife Osman'ın bu arazileri iktâ olarak vermesinin en önemli nedenlerinden biri de gelirlerin azalmasından dolayı içine düştüğü mali krizden kurtulma çabasıdır. Bilindiği gibi Hz. Osman'ın halifeliğinin sonlarına doğru fetihlerin durması, cizye verenlerin Müslüman olması gibi nedenlerle hazine gelirlerinin azalması neticesinde ekonomik birtakım sıkıntıların yaşanmasına zemin hazırlamıştır. Ekonomik nedenler, siyasi problemlerin doğmasını tetiklemiş ve bu da toplumda huzursuzlukların baş göstermesine neden olmuştur. Halife de bu buhrandan çıkmak amacıyla Irak bölgesinde bulunan arazilerinin bir kısmını Kureyşlilerden bazılarına iktâ etmiştir. Bu durum hayatlarını ganimetlerle idame ettirmeye alışan kabilelerin öfkelenmesine neden olmuştur. Dolayısıyla Hz. Osman, bu durumu idare etmekte zorlanmış, halkın üzerindeki otoritesini kaybetmiştir. Bunun akabinde Irak bölgesinde halifeye karşı ciddi bir muhalefet oluşmaya başlamıştır. ${ }^{87}$

\footnotetext{
84 Ebû Ubeyd, Kitâbü'l-emvâl, 370, 371; İbn Zenceveyh, Kitâbu'l-emval, 624; Belâzurî, Fütûhu'l-büldân, 489, 490; Yahya b. Âdem, Kitâbü'l-harâc, 111, 113 .

85 Ebû Ubeyd, Kitâbü'l-emvâl, 375-376.

86 Yeniçeri, İslâm İktisadının Esasları, 49.

87 Mehmet Mahfuz Söylemez, “Hz. Osman Dönemindeki Ekonomik Krizin Garnizyon Kentlere Etkisi-Kufe Örneği", Gazi Üniversitesi Çorum İlahiyat Fakültesi Dergisi 2/3 (2003), 72, 84.
} 
Hz. Ali, halife olduğunda daha önce Kûfe' de Hz. Osman döneminde Kureyşlilerin ileri gelenlerine iktâ olarak verilen arazileri, ellerinden aldı ve beytülmâle devretti. Böylece Hz. Osman'ın halifeliği döneminde büyük sıkıntılara sebebiyet veren bu olay da çözülmüş oldu..$^{88}$

Halife Osman, iktânın dışında da halka bazı araziler verdiği bilinmektedir. Şöyle ki halktan birtakım arazileri alarak yerine başka bir yerde arazi vermiştir. Dolayısıyla herhangi bir amaçla bir bölgeden başka bir bölgeye gitmek isteyenler için topraklarını takas etme fırsatını vermiştir. Bu da yatırım yapmak isteyenlerin önünü açmıştır. Nitekim Taif, Yemen, Bahreyn, Hadramut ve Umman gibi yerlerden ticaret yapmak amaciyla arazilerini bırakarak gelen kişilere yeni araziler vermiştir. ${ }^{9}$

Hz. Osman' ın en önemli özelliği, hazineye ait olan arazileri, belirli insanlara iktâ olarak verip karşılı̆̆ında ücret almasıydı. Onun zamanında iktâ gelirleri, devletin en önemli gelir kaynaklarından biri kabul edilmiştir. Bu şekilde elde edilen gelirler, ihtiyaç görülen yerlere harcanmıştır. Hz. Osman'ın bu uygulamaları, Emevi halifelerinden Abdulmelik b. Mervân döneminde yaşanan Cemâcim Vak'ası'na kadar devam etmiştir. Bu olay esnasında arazi kayıtlarını ihtiva eden defterler yakılmış, kabile mensupları ele geçirebildikleri arazileri almışlardır..$^{90}$

Mevât ve savâfî arazilerin tasarrufu halifelerin yetkisindeydi. Dolayısıyla uygun gördüğü kişilere bunu iktâ etmesi onların hakkıydı. Hz. Ömer de savâfî topraklardan bir kısmını ehil olan kişilere iktâ olarak vermiştir. Hz. Osman, Hz. Ömer'in uygulamalarını devam ettirmekle birlikte daha da genişletmiştir. Bu durum eleştirilere sebep olmuştur. Halife, bu eleştirileri kabul etmemiş ve bu toprakların fethedildiği günden beri başta muhacir ve ensar olmak üzere birçok kişiye iktâ yoluyla verildiğini, elde edilen gelirler sayesinde halkın ihtiyaçlarının karşılandığını ifade etmiştir. ${ }^{91}$

Bazı kaynaklarda geçen bilgilere göre Hz. Ömer'in herhangi birinin eline geçmesin diye arazileri iktâ olarak vermediği hatta Hz. Osman'dan önce yöneticilerin arazileri iktâ etmediğini, bu yolla toprak veren ilk kişinin Hz. Osman olduğu bildirilmektedir.92 Ancak

\footnotetext{
88 Muhammed Âbid el-Câbirî, Arap-İslam Siyasal Akll, çev. Vecdi Akyüz (İstanbul: Kitabevi Yayınları, 2001), 249; Mehmet Mahfuz Söylemez, Bedevîlikten Hadârîliğe Kufe (Ankara: Ankara Okulu Yayınları, 2001), 273.

89 İbn Zenceveyh, Kitâbu'l-emval, 635; Demirci, “İkta”; Murat Akarsu, Hz. Osman (Ankara: Ankara Okulu Yayınları, 2015), 127.

90 Mâverdî, el-Ahkâmü's-sultaniyye, 2006), 288.

91 Mâverdî, el-Ahkâmü's-sultaniyye, 288; Abdulazîz Dûrî, İlk Dönem İslam Tarihi, çev. Hayrettin Yücesoy (İstanbul: Endülüs Yayınları, 2016), 112-113.

92 Belâzurî, Fütûhu'l-büldân, 382. Ebu Zeyd Ömer b. Şebbe, Târîhu'l-medineti'l-münevvere, thk. Muhammed Şeltût (Cidde, 1399/1978), 3/1019.
} 
yukarıda ifade edildiği gibi Hz. Osman'dan önce hem Hz. Peygamber hem de Hz. Ebû Bekir ve $\mathrm{Hz}$. Ömer, çeşitli vesilelerle halka iktâ yoluyla arazi vermişlerdir.93

Hz. Ömer'in ölü arazilerinin boş kalmasına rıza göstermediği ve bunu çeşitli vesilelerle muhtelif kişilere iktâ yoluyla verdiğini ifade ettik. Ayrıca halife, bu arazileri tarıma kazandırarak âtıl kalmasını engellemek amacıyla iktâ etmiş ancak üç sene boş bırakanların arazilerini ellerinden almıştır. Dolayısıyla onun döneminde savâfi arazisini işletmek için kimseye vermeyip boş kalmasına sebep olması ve Müslümanların faydasına olacak şekilde kimseye tahsis etmemesi kendi yönetim anlayışıyla bağdaşmadığı anlaşılmaktadır.

\section{5. Çeșitli Vesilelerle Verilen İktâlar}

Yukarıda halifelerin hangi amaçla halka iktâ verdikleri üzerinde duruldu. Bunların dışında kaynaklarda halifelerin bazı şahıslara belirli arazileri iktâ ettikleri fakat bunları hangi amaçla verdikleri bilinmemektedir. Mesela Yahya b. Âdem, Hz. Ömer'in Abdullah b Mes' ûd, Sa'd b. Ebî Vakkas, Usame, Habbab ve İbn Zeyd gibi bazı kişilere çeşitli yerleri iktâ ettiğini bildirmekle birlikte ${ }^{94}$ bunlara hangi arazileri ve ne maksatla verdiğini açılamamıştır. Öte yandan Belâzurî, Halife Ömer'in Mısır'ın fethi için Amr b. el-Âs'a takviye güç olarak gönderdiği birliğin başında bulunan Zübeyr b. Avvam'a, bölgenin fethinden sonra iki toprak parçasını verdiğini aktarmıştır. ${ }^{95}$ Halife, aynı şahsa Akîk bölgesinde de toprak vermiştir. ${ }^{96}$ Fakat olayın detayları açıklanmamıştır. Aynı şekilde Hz. Ömer, Hz. Ali'ye Yenbu' arazisini, ${ }^{97}$ Müccâ'a b. Mürâre'ye de er-Reyyâ bölgesini iktâ etmiştir.98

Hz. Osman gerek ashâbtan ve gerekse halktan uygun gördüğü şahıslara arazilerin bir kısmını iktâ olarak tahsis etmiştir. Sa'd b. Ebî Vakkas, Zübeyr b. Avvâm ve Üsame b. Zeyd'e99 bazı arazileri iktâ olarak vermiştir. ${ }^{100}$ Ayrıca Abdullah b. Mesud'a Bahreyn'de bir arazi ve Sa'd

\footnotetext{
93 Yahya b. Âdem, Kitâbü'l-harâc, 111-115. Mâverdî, el-Ahkâmü's-sultaniyye, 288; Sallabi, II. Halife Hz. Ömer'in Hayatı, 347; Mustafa Fayda, Hz. Ömer Zamanında Gayrimüslimler (İstanbul: MÜIF. Yayınları, 1989), 38.

94 Yahya b. Âdem, Kitâbü'l-harâc, 112.

95 Belâzurî, Fütûhu'l-büldân, 300.

96 Belâzurî, Fütûhu'l-büldân, 31.

97 Yahya b. Âdem'in rivayetine göre Hz. Ali, Hz. Ömer'den toprak istemiş, o da ona Yenbu' arazisini bölüp vermiş ve bu araziden bol su çıkmıştır. Daha sonra Hz. Ali, bu araziyi fakirler için vakfetmiştir. Bk. Kitâbü'l-harâc, 112; Ekrem Ziyâ el-Ömerî, Asru'l-hilâfeti'r-raşide, 242; Ayrıca bk. Semhûdî, Vefâ 'ü'l-vefâ bi-ahbâri dâri'l-Mudtafâ, 4/166; Sallabi, II. Halife Hz. Ömer'in Hayatı, 347.

98 Ebû Ubeyd, Kitâbü'l-emvâl, 368, 373-374; Belâzurî, Fütûhu'l-büldân, 126-127.

99 Ebû Ubeyd, Kitâbü'l-emvâl, 371; İbn Zenceveyh, Kitâbu'l-emval, 624; Belâzurî, Fütûhu'l-büldân, 381.

${ }^{100}$ Belâzurî, Fütûhu'l-büldân, 381.
} 
b. Mâlik ez-Zührî'ye bazı yerleri vermiş, bunlar da kendilerine verilen bu toprakların belirli bir oranını başkalarıyla ortak işletmişlerdir. ${ }^{101}$

Belâzurî’nin aktardığına göre Hz. Osman, Mücâ'a b. Mürâre'ye bazı toprakları iktâ etmiştir. Fakat ravi halifenin hangi bölgeyi iktâ ettiğini hatırlamadığını ifade etmektedir. ${ }^{102}$ Ayrıca Hz. Osman, Ammar b. Yasir'e İstinye'yi, Hüseyin b. Ali ile Şüreyh'e bazı toprakları, Habbab b. Eret'e Sa'nebâ'yı, Sa'd b. Mâlik'e de Hürmüz köyünde bir araziyi, ${ }^{103}$ Talha b. Ubeydullah'a Neşâstec'i, Adiyy b. Hatim et-Tâî'ye er-Revaha'ya, Eş'as b. Kays el-Kindî'ye Tîzenâbâz'ı, Vâil b. Hucr el-Hadramî'ye Zürâre'ye ait topraklara bitişik yerleri, Cerir b. Abdullah el-Becelî'ye Fırat Nehri kenarındaki bazı toprakları, Hâlid b. Urfuta'ya Hammam A'yen yanındaki bir toprağ

\section{6. İktânın Verilme Süresi}

Sahibi olmayan toprakların mülkiyeti kamuya geçtiğinden yetkililer, bu arazileri çeşitli vesilelerle uygun gördüğü kişilere vermişlerdir. Herhangi bir araziyi işlemek amacyyla alanlar, şartlarını yerine getirdikleri müddetçe arazi üzerinde tasarruf yetkisine sahip olurdu. Dolayısıyla araziyi iktâ usulüyle alan kişilerin arazi üzerindeki hakkı, toprakları değerlendirmelerine bağlıdır. Toprağı ekmedikleri takdirde işleme hakları ellerinden alınmıştır. Öte yandan herhangi bir arazi ihyâ ve imar edilmeden önce birtakım çalışmalar yapılmış veya bazı işaretlerle arazi çevrilmesine rağmen -ki buna tehcir deniliyordu- belli bir müddet işlenmez ve boş bırakılırsa bunu yapan kişiler, haklarını kaybediyorlardı. ${ }^{105}$ Dolayısıyla işlenmeyen toprak, insanlığın menfaati açısında kayıp olarak değerlendiriliyordu. Bu durumda hem birey hem de devlet zarar görmüş oluyordu. Genelin menfaati için toprağın sürekli işlenmesi gerekiyordu.

Halifeler, yasaklamadıkça prensip itibariyle bireyler bu arazileri ihyâ edebiliyorlardı. Nitekim Hz. Peygamber, bu konuda şöyle buyurmuştur: "Herkim ölü bir araziye hayat verirse

\footnotetext{
${ }^{101}$ Ebû Yusuf, Kitabü'l-harâc, 62; Belâzurî, Fütûhu'l-büldân, 381.

102 Ebû Ubeyd, Kitâbü'l-emvâl, 368, 373-374; Belâzurî, Fütûhu'l-büldân, 126-127.

${ }^{103}$ Ebû Yusuf, Kitabü'l-harâc, 62; İbn Şebbe, ârîhu'l-medineti'l-münevvere, 3/1019-1020; Belâzurî, Fütûhu'l-büldân, 381; Taberî, Târîhu'r-rusûl ve'l-mulûk, 3/589.

${ }^{104}$ Belâzurî, Fütûhu'l-büldân, 381, 382; İbn Şebbe, Târîhu'l-medineti'l-münevvere, 3/1019; Ekrem Ziyâ el-Ömerî, Asru'lhilâfeti'r-raşide, 244.

105 Ebû Yusuf, Kitabü'l-harâc, 63; Ebû Davud, "Kitabü'l-Harâc", 35-37; Sadr, İktisâdunâ, 467, 511; Muhammad Hamidullah, el-Vesâiku's-siyâsiyye, 293-295.
} 
o arazi kendisine kalır. Şayet üç yıl o toprağı ekmezse bu hakkını kaybeder."106 Dolayısıyla mevât bir araziyi ihyâ ettikten sonra üç yıl boş bırakan kişinin toprak üzerinde herhangi bir hakkı kalmıyordu. Netice itibariyle herhangi bir şahıs mevât bir arazinin etrafını çevirdikten sonra kendisine üç yıl izin verilirdi. Çünkü daha önce emek verdiğinden o toprakta hakkı vardı. Ancak arazi elinde üç yıl kaldığı halde imar etmezse toprak üzerindeki haklarını kaybetmiş olurdu. Zira kendine tanınan süreyi iyi değerlendirmemiş ve arazi üzerinde herkes, eşit hakka sahip olmuştur. ${ }^{107} \mathrm{Bu}$ sistem, Müslümanların menfaatine, memleketin imarına hizmet etmek düşüncesiyle kurulmuştur. ${ }^{108}$ Arazilerin boş bırakılması genel menfaate aykırı olarak değerlendirilmiştir.

Vergiye tabi tutulan iktâ arazileri belirlenen sürede tarımsal üretime geçilmediği takdirde ellerinden alınmıştır. ${ }^{109}$ Nitekim Hz. Ömer'in halifeliği zamanında bazı kişiler, hazineye ait boş arazileri almışlar fakat bu arazileri imar etmedikleri gibi etrafını duvarla örüp sahiplenmişlerdi. Ellerinde bulunan toprakları değerlendirmedikleri gibi kendi mülkleri olduğunu iddia ediyorlardı. Bu durumdan haberdar olan Hz. Ömer, son derece kızmış ve minbere çıkarak Allah Resulü'nün şu sözünü insanlara hatırlatmıştır: “Her kim ölü bir toprağ1 ihyâ ederse o toprak, ihyâ edenindir. Elinde bulunan toprağ 1 üç sene boş bırakırsa bu hakkını kaybeder." 110

Ebû Yusuf, Allah Resulü'nün Benî Nadîr Yahudilerinden Curf adında hurmalık bir araziyi Urve b. Zübeyr'e verdiğini ve bu arazinin daha sonra Hz. Ömer'in bazı kişilere verdiği arazilerle karıştırıldığını aktarır. Urve, söz konusu araziyi almış ancak işlemeyip öyle bırakmıştı. Çıkan anlaşmazlıklar sebebiyle halife, “Hazineden pay isteyenler, bugüne kadar neredeydiler? Demek ki kendilerinde hayır yoktur. O zaman bu arazilerin tasarrufu bendedir. Onları dilediğime vereceğim." O esnada orada bulunan Havvat b. Cübeyr, mezkûr araziyi halifeden istedi. Halife de isteğini yerine getirdi. ${ }^{111}$ Aynı şekil de Hz. Ömer, “Her kim hazineye ait bir araziyi alır, elinde üç yıl kaldığı halde onu işlemezse ve bir başkası gelip o araziyi imar ederse, imar edenler bu araziyi almada daha fazla hak sahibidirler."112 Rivayet edildiğine göre

\footnotetext{
106 Tirmizî, Ebû Îsâ Muhammed b. Îsâ, el-Câmiu'l-kebîr (Beyrut: Dâru'l-Garbi'l-İslâm, 1996), "Ahkâm", 38; Ebû Yusuf, Kitabü'l-harâc, 63; Yahya b. Âdem, Kitâbü'l-harâc. 115, 117; Ebu Zehra, İslâmda Sosyal Dayanışma, 93; Yeniçeri, İslâm İktisadının Esasları, 52.

107 Ebû Yusuf, Kitabü'l-harâc, 1011; Ebu Zehra, İslâmda Sosyal Dayanışma, 93.

108 İsmet Kayaoğlu, İslâm Kurumlar Tarihi (Ankara: Ankara Üniversitesi Basımevi, 1985), 87.

${ }^{109}$ M. A. Mannan, İslâm Ekonomisi Teori ve Pratik, 166.

110 Tirmizî, Ahkâm, 38; Ebû Yusuf, Kitabü'l-harâc, 63; Ebû Ubeyd, Kitâbü'l-emvâl, 383.

${ }^{111}$ Ebû Yusuf, Kitabü'l-harâc, 61.

112 Ebû Yusuf, Kitabü'l-harâc, 61; Sadr, İktisâdunâ, 472.
} 
Allah Resulü'nün Medine ile deniz arasında Sahr dağı eteklerinde kalan ve Akîk bölgesi ${ }^{113}$ olarak bilinen toprakları Bilâl b. Haris el-Müzeni'ye vermiş, ${ }^{114}$ bunu bir vesika ile belgelemişti. ${ }^{115}$ Ancak Bilal bu arazilerin hepsini işleyememiştir. Hz. Ömer halife olduğunda, “Resulüllah bu toprakları sana işleyesin diye iktâ etti. Ancak buna gücün yetmiyor. İşleyebildiğin kadarını al gerisini bize ver." dedi. ${ }^{116}$ Bilâl, bu duruma itiraz edip Hz. Peygamber'in kendisine verdiği vesikayı gösterse de halife onu dinlemedi. "Hz. Peygamber, bu geniş ve uzun araziyi sana verdiği zaman Müslümanlar azdı ve ihtiyaçları pek yoktu. Ancak şimdi Müslümanlar alabildiğine çoğaldı. Dolayısıyla onların da bu arazilere ihtiyaçları var. Bunların hepsine sahip olman doğru değildir." diyerek itirazını kabul etmedi. Böylece Hz. Ömer, Bilâl'in işleyemediği kısımları ondan aldıktan sonra parsellere ayırdı ve uygun bulduğu kişilere iktâ etti. ${ }^{117}$

Kaynaklarda geçen bilgilere göre Allah Resulü, Cüheyne veya Müzeyne kabilesine mensup bazı kişilere belirli bir bölgeyi iktâ olarak vermiştir. Fakat bu kişiler, aldıkları bu arazileri imar etmeyerek âtıl bırakmışlardı. Başkaları gelip söz konusu araziyi imar edince iki grup arasında münakaşa çıkmıştır. Allah Resulü'nün kendilerine iktâ verdiği kişiler, şikâyet etmek amacıyla dönemin halifesi Hz. Ömer' in yanına gitmişlerdir. ${ }^{118}$ Halife de şöyle demiştir: Bu toprağı işleyen kişilere müdahale etmediniz. Bunlar bu araziyi imar ettikten ve belirli bir mahsul aldıktan sonra müdahil oldunuz. ${ }^{119}$ Şayet ben veya Ebû Bekir bu araziyi size vermiş olsaydık, onu hemen sizden geri alırdım. Fakat onu Allah Resulü verdiği için durum değişmiştir." dedikten sonra sözlerini şöyle sürdürmüştür: "Bir kimseye herhangi bir arazi iktâ edildiği halde, o kişi aldığı araziyi üç sene işlemediği takdirde başkaları gelip o araziyi imar ederse, imar edenler söz konusu arazi üzerinde daha fazla hak sahibidirler. ${ }^{120}$ Böylece Hz. Ömer, mezkûr arazinin hem ma'mur hem da gayri ma' mur kıymetini belirledikten sonra

\footnotetext{
${ }^{113}$ Akik bölgesi hakkında detaylı bilgiler için bk. Yakut, Mu'cemü'l-buldân, 4/138-139; İdris Bostan, “Akîk”, Türkiye Diyanet Vakfi İslâm Ansiklopedisi (İstanbul: İsam, 1989).

${ }^{114}$ Ebû Yusuf, Kitabü'l-harâc, 61; Ebü'l-Hasen Muhammed b. el-Hasen b. Zebâle el-Medenî el-Mahzûmî İbn Zebâle, Ahbâru'l-Medine, çev. Fatih Mehmet Yılmaz (Ankara: Ankara Okulu Yayınları, 2018), 169; Ebû Ubeyd, Kitâbü'lemvâl, 374; Yahya b. Âdem, Kitâbü'l-harâc, 112.

115 Belgenin detayları için bk. Muhammad Hamidullah, el-Vesâiku's-siyâsiyye, 293-295.

${ }^{116}$ Ebû Ubeyd, Kitâbü'l-emvâl, 382-383; İbn Zenceveyh, Kitâbu'l-emval, 614; Semhûdî, Vefâ' '̈̈l-vefâ bi-ahbâri dâri'lMudtafâ, 3/188.

117 Ebû Yusuf, Kitabü'l-harâc, 61; İbn Zebâle, Ahbâru'l-Medine, 169-170; Yahya b. Âdem, Kitâbü'l-harâc, 112; Semhûdî, Vefầ'̈̈'l-vefâ bi-ahbâri dâri'l-Mudtafâ, 3/187-189.

118 Ebû Yusuf, Kitabü'l-harâc, 61.

119 Ebû Ubeyd, Kitâbü'l-emvâl, 381.

${ }^{120}$ Ebû Yusuf, Kitabü'l-harâc, 61.
} 
arazinin ilk sahiplerine, “Dilerseniz aradaki farkı ödeyin, toprağı geri alın veya onlar size arazinin ma'mur edilmeden önceki bedelini ödesinler, arazi onların olsun." dedi. ${ }^{121}$

Görüldüğü gibi Hz. Ömer, halkın genel menfaatini göz önünde bulundurarak hareket etmiştir. Arazileri, Allah Resulü iktâ etmiş olsa bile hakkını vermedikleri zaman ellerinden almıştır. Ancak araziyi aslına uygun olarak kullanacaklarına inanırsa o takdirde Allah Resulü'nün verdiği arazilere dokunmamıştır. Nitekim Hz. Ömer, Allah Resulü'nün bazı kişilere iktâ yoluyla arazi verdiğini öğrenince kendisi de o kişilerden arazileri geri almamıştır. Zira Ebû Ubeyd'in naklettiğine göre Temim ed-Darî, Müslüman olduktan sonra, Hz. Peygamber'in yanına gider, kendisinden Suriye bölgesinde bulunan ve aynı zamanda memleketi olan Hz. İbrahim, Hz. İshak ve Hz. Yakup peygamberlerin bulunduğu arazi ile Beyt Lahim'deki araziyi talep eder. Bunun üzerine Allah Resulü, söz konusu arazileri Temim'e verir ve bunu belgelendirir. Daha sonra Hz. Ömer döneminde, Suriye bölgesi fethedildiğinde Temim ed-Darî, Hz. Ömer'e gider ve durumu arz ettikten sonra Resulüllah'ın kendisine verdiği belgeyi gösterir. Halife de araziyi satmama koşuluyla kendisine iktâ eder. ${ }^{122}$

Hz. Ömer, bu sayede ölü arazilerin ihyâ etmesine vurgu yaparak tarımda sürekliliği teşvik etmiştir. ${ }^{123}$ Onun bu davranışı hilafetin idari merkezi olan Medine ile münhasır kalmamış, yazılı bir vesika ile taşrada bulunan valilerine de göndermiştir. ${ }^{124}$

Konuyu değerlendiren Muhammed Bakır es-Sadr, arazilerin genel mülkiyetinin özel mülkiyetle aynı paralelde olmadığını ifade etmiştir. Herhangi biri, âtıl bir toprağı, ma'mur hale getirdiğinde ondan faydalanabilir ancak genel mülkiyetin kapsamında bulunan bu arazilerin üzerinde hak iddia edemez. ${ }^{125}$ Yani kısacası bu tür arazilerin tasarruf yetkisi şartlara uyulduğu müddetçe araziyi ma'mur edenin iken genel yetki ise devlete aittir.

Ebû Ubeyd, herhangi birinin zimmetinde olmayan toprakların hazinenin mülkü, tasarruf yetkisinin ise devlet başkanına ait olduğunu belirtir. ${ }^{126}$ Yahya b. Âdem, mevât araziyi bu şekilde ihyâ eden kişilerin bu topraklar üzerinde işleme hakkı olduğu gibi ebediyen onun mülkü haline geldiğini, miras olarak bırakabileceğini, dilerse onu satabileceğini ve toprağı âtıl

\footnotetext{
${ }^{121}$ Ebû Ubeyd, Kitâbü'l-emvâl, 381 .

${ }^{122}$ Ebû Ubeyd, Kitâbü'l-emvâl, 368-369; İbn Zenceveyh, Kitâbu'l-emval, 614; Muhammed Hamidullah, İslam Peygamberi, $1 / 617$.

${ }^{123}$ Cureybe b. Ahmed b. Sünyâh el-Hârisî Hârisî, Fıkhu'l-iktisâdîli emîri'l-mü'minîn Ömer b. El-Hattâb (Cidde: Dâru'lEndülüs, 2003), 4104.

124 Yahya b. Âdem, Kitâbü'l-harâc, 118.

${ }^{125}$ Sadr, İktisâdunâ, 462.

${ }^{126}$ Ebû Ubeyd, Kitâbü'l-emvâl, 371.
} 
bıraksa bile onun mülkünden çıkmadığını ifade eder. ${ }^{127}$ Ancak onun bu görüşleri, Hz. Ömer'in uygulamalarıyla çelişmektedir. Zira iktâ olarak alınan bir arazi, ebedi olarak kişinin mülkü haline gelmemiş, belli bir süreliğine âtıl bıraktığı takdirde halife, o toprağı elinden almıştır. ${ }^{128}$

Kişi, şartlarını yerine getirdiği takdirde bu arazileri miras olarak bırakabileceği gibi bir başkasına da satabilir. Nitekim Hz. Ömer, ensardan Havvât b. Cübeyr'e boş bir toprağı iktâ olarak vermiş, o da bu araziyi daha sonra satmıştır. ${ }^{129}$ Ancak bu araziyi satan da alan da genel mülkiyetin devlete ait olduğunu bilir, ona göre akit gerçekleşir. Genel mülkiyetin devlete ait olduğu konusu yukarıda örneklerle açıklanmıştır.

Devlet hazinesinden iktâ yoluyla arazi verilen kişilere, aldıkları arazileri işleyebilmeleri için kendilerine genellikle izin belgesi veriliyordu. Böylece bir başkasının bu topraklar üzerinde herhangi bir tasarruf yetkisi kalmıyordu. ${ }^{130}$ Nitekim Hz. Ebû Bekir, Hz. Peygamber gibi hazine arazisini belirli insanlara iktâ olarak verdiğinde, arazinin işleme yetkisinin kendilerine ait olduğuna dair bir vesika vermiştir. Rivayet edildiğine göre Hz. Ebû Bekir, Talha b. Ubeydullah'a bir bölgeyi iktâ olarak vermiş ve bunu belgelemek için bir de vesika vermiştir. Ancak aralarında Hz. Ömer'in de bulunduğu bazı kişileri şahit göstermek istemiştir. Talha, elindeki belgeyi Hz. Ömer'e imzalatmak isteyince Hz. Ömer, başka insanların da bu toprakta hakkı olduğu gerekçesiyle belgeyi imzalamamıştır. Bu duruma tepki gösteren Talha, durumu Halife Ebû Bekir'e bildirmiş, Hz. Ebû Bekir de Hz. Ömer'in söylediklerine hak vermiş ve ona rağmen bir şey yapamayacağını uygun bir dille bildirmiştir. ${ }^{131}$ Benzer bir olay da Hz. Ebû Bekir ile Uyeyne b. Hısn arasında yaşanmıştır. ${ }^{132}$

\section{7. İktâdan Alınan Vergi Miktarı}

Dört Halife Dönemi'nde savâfî ve mevât araziler, yukarıda ifade edildiği gibi işlenip imar edilmesi ve verimli bir hale gelmesi için uygun kişilere iktâ olarak verilmiş, bunun karşılığında da vergi alınmıştır. Bu verginin türünü yani öşür veya haraç olduğuna devlet başkanları karar vermişlerdir. Halifeler, bu tür vergileri aldıklarında, istisnası olmakla birlikte, genellikle Müslümanlardan alınan öşür vergisi gibi değerlendirmişlerdir. ${ }^{133}$

\footnotetext{
127 Yahya b. Âdem, Kitâbü'l-harâc, 121.

${ }^{128}$ Ebû Yusuf, Kitabü'l-harâc, 61.

${ }^{129}$ Belâzurî, Fütûhu'l-büldân, 21.

130 Sadr, İktisâdunâ, 467-511; Muhammad Hamidullah, el-Vesâiku's-siyâsiyye, 293-295.

${ }^{131}$ Ebû Ubeyd, Kitâbü'l-emvâl, 370; İbn Zenceveyh, Kitâbu'l-emval, 622, 623; Yeniçeri, İslam'da Devlet Bütçesi, 63.

132 Ebû Ubeyd, Kitâbü'l-emvâl, 370; Muhammed Abdulhay Kettânî, et-Teratibu'l-idâriyye (Beyrut,: Darü'l-Erkam b. Ebi'l-Erkam, ts.), 1/201; Ekrem Ziyâ el-Ömerî, Asru'l-hilâfeti'r-raşide, 241.

${ }^{133}$ Abdulazîz Dûrî, İslam İktisat Tarihine Giriş, 2014), 36.
} 
Belâzurî, Sasanilere karşı kazanılan Kâdisiyye ve Medâin savaşlarından sonra oranın yerel halkının çıkıp gittiğini, toprakların ve su kuyularının Müslümanların eline geçtiğini, bunların Müslüman halka dağıtıldığını ve bu yerlerin öşür arazisi olarak kabul edildiği için âmiller aracılığıyla zekât alındığını ifade etmektedir. ${ }^{134}$

Ebû Yusuf da bu tür toprakların öşür arazisi statüsünde olduğunu ve bunlardan zekât alındığını ifade etmiştir. Şayet mevât araziler için kuyu kazılır, kanallar açılırsa yani bir emek söz konusuysa artık bu durumda bunun haraç arazisi olma şansı kalmazdı. Ancak bu araziler haraç araziler için ayrılan su ile sulanıyorsa haraç arazisi kabul edilir ve ona göre vergi alınırdı. ${ }^{135}$ Sevad ve benzeri araziler, genel olarak haraç suyu ile sulandığından haraç arazisi olarak kabul edilmiş ve ona göre vergi alınmıştır. Savaşlarda Müslümanların eline geçen ve halifeler tarafından belirli kişilere tahsis edilen beylik arazileri de bu kategoride değerlendirilmiştir. ${ }^{136}$

Sonuç olarak iktâ edilen topraklar, halifelerin tasarrufunda olup haraç arazisi olarak kabul edilmişse ondan haraç vergisi, öşür arazisi olarak değerlendirilmişse öşür vergisi alınırd1. ${ }^{137}$

İktâ olarak verilen topraklardan alınan vergi miktarına gelince, şayet toprak öşür arazisi olarak kabul edilmişse onda bir veya yirmide bir; ${ }^{138}$ haraç arazisi olarak kabul edilmişse o takdirde vergi miktarı, anlaşmaya bağlıdır. Yani hem toprağın kendisinden hem de araziden elde edilen üründen alınabiliyordu. Zira haraç arazisinden elde edilen vergi iki şekilde tahsil ediliyordu. Bunlardan birincisi, topraktan değil de üründen alınan vergidir ki buna haraç-ı mukasseme; ikincisi ise toprağın verimi dikkate alınarak belirlenen vergidir. Buna da haraç-ı vazife deniliyordu. ${ }^{139}$

\section{Sonuç}

Arap Yarımadası'nın Hicaz Bölgesi'nde tarım yapılmakla birlikte çevre ülkelere oranla istenilen boyutta değildi. Bunun içindir ki Hz. Peygamber'den önce Hicaz Bölgesi'nde iktâ hususundan pek bahsedilemez.

\footnotetext{
${ }^{134}$ Belâzurî, Fütûhu'l-büldân, 419.

135 Ebû Yusuf, Kitabü'l-harâc, 58, 65-66; Sadr, İktisâdunâ, 465-467.

${ }^{136}$ Ebû Yusuf, Kitabü'l-harâc, 58-59.

${ }^{137}$ Ebû Yusuf, Kitabü'l-harâc, 65.

${ }^{138}$ Belâzurî, Fütûhu'l-büldân, 380; Öşürün miktarı hakkında detaylar için bk. Buhârî, Zekât, 55; İbn Mâce, Zekât, 17.

${ }^{139}$ Mâverdî, el-Ahkâmü's-sultaniyye, 190-191.
} 
Hz. Peygamber döneminde hicretle birlikte Medine'ye göç etmek zorunda kalan muhacirlerin barınma ve iaşelerini temin etmek amacıyla sahipleri bulunmayan mevât araziler, Hz. Peygamber'in talimatıyla ihtiyaç sahiplerine verilmiştir. Hz. Peygamber'in dağıttığı arazilerin belli bir kısmı iskân amaçlı olmakla birlikte arazileri tarıma kazandırarak verimi artırmak, insanların kalplerini İslâm'a 1sındırmak, yeni yerlerin fethini kolaylaştırarak Müslümanları cihada teşvik etmek ve Müslüman olmayanların düşmanlıklarını minimum seviyeye indirmek gibi amaçlarla da araziler tahsis edilmiştir.

Hulefâ-yi Râşidîn Dönemi'nde iktâ olarak verilen araziler, Müslümanların eline geçen ve kraliyet ailesine ait araziler ile savaşlarda ölen ve kaçanlara ait olup sahibi belli olmayan ma'mur arazilerdir. Halifelerin bireylere mülk olarak verdikleri araziler, genellikle daha önce işlenmemiş çorak arazilerdir. Temlik olarak değil de faydalandırma veya vergi almak amacıyla verilen araziler ise daha çok fetihlerle ele geçirilmiş ve sahipleri belli olmayan ma'mur arazilerdir.

Dört Halife Dönemi'nde Irak, Suriye ve Misır bölgesi fethedildiğinde çeşitli nedenlerden dolayı Müslümanların eline geçen mâmur topraklar, hazineye devredilmiştir. Bu tür araziler savafî olarak değerlendirilmiş ve halka iktâ olarak verilmiştir.

İktâ olarak verilen bir başka arazi çeşidi ise mevât arazilerdir. Bu tür araziler, genel olarak yerleşim ve üretim gibi bir amaçla kullanılmayan, herhangi birinin mülkünde bulunmayan, suyun ulaşması zor olan, daha önce tarım yapılmayan veya bataklık olarak kabul edilen yerlerdir. Bu tür arazileri belirli bir emek sonucu tarıma kazandırmak ve faydalı bir hale getirmek ise onu ihyâ etmektir.

Râşid Halifeler Dönemi'nde iktâ edilen arazilerin bir kısmı iskân amaçlıydı. Zira fethedilen yeni yerlerde bulunan halkın Müslümanlarla tanışması ve İslâm'ın insanlar arasında kalıcı hale gelebilmesi için Müslümanlar bu yeni yerlere yerleşme konusunda teşvik edilmişlerdir. Bu sayede bölgelerin Müslümanlaşması hızlanmıştır. Hz. Ömer, döneminde ordugâh amaciyla kurulan yeni şehirlere yerleştirilen kabilelere iskân amaciyla toprak verildiği gibi sınırların güvenliğini sağlamak amacıyla gönderilen askerlere de araziler iktâ edilmiştir.

Halka iktâ olarak verilen arazilerin bir amacı da hazineye gelir getirmesiydi. Bu amaçla idareciler, savâfî topraklarını halka iktâ olarak vermişler ve bunun karşılığında onlardan vergi almışlardır. Bu yolla arazileri iktâ eden ilk kişinin Hz. Osman olduğu ile ilgili bilgiler gerçeği 
yansıtmamaktadır. Nitekim görüldüğü üzere önceki halifelerin de arazileri iktâ ettiği bilinmektedir.

Sahibi olmayan topraklar ile savâfî arazilerin mülkiyeti kamuya geçtiğinden halifeler, bu arazileri çeşitli vesilelerle uygun gördüğü kişilere veriyorlardı. Herhangi bir araziyi işlemek amacıyla alan kişiler, şartlarını yerine getirdikleri müddetçe arazi üzerinde tasarruf hakkına sahiptiler. Üç yıl boyunca toprağı âtıl bıraktıkları takdirde kendilerine iktâ edilen bu araziler ellerinden alınırdı.

Dört Halife Dönemi'nde savâfî ve mevât araziler, işlenip imar edilmesi ve verimli bir hale gelmesi için iktâ olarak verilmiş, bunun karşılığında da vergi alınmıştır. Bu verginin türünü yetkililer belirlemiş öşür ya da haraç alınmıştır. Haraç topraklarından olmayan bir arazi Müslüman bir kimseye iktâ edildiğinde ondan ancak öşür alınmıştır. Genellikle öşür vergisi alınmakla birlikte şartlar tahakkuk ettiğinde haraç vergisi de alınmıştır. 


\section{Kaynakça}

Akarsu, Murat. Hz. Osman. Ankara: Ankara Okulu Yayınları, 2015.

Algül, Hüseyin. "Hadramut”. Türkiye Diyanet Vakfı İslâm Ansiklopedisi. Erişim 7 Temmuz 2020. https://islamansiklopedisi.org.tr/hadramut

Ali Muhammed Sallabi. II. Halife Hz. Ömer'in Hayatı, Şahsiyeti ve Dönemi. çev. Mehmet Akbaş. İstanbul: Ravza Yayınları, 2008.

Belâzurî, Ahmed b. Yahya b. Câbir b. Davud el-Belâzurî. Fütûhu'l-büldân. Beyrut: Mektebetü'lMeârif, 1987.

Bostan, İdris. "Akîk". Türkiye Diyanet Vakfı İslâm Ansiklopedisi. Erişim 20 Mayıs 2020. https://islamansiklopedisi.org.tr/akik--medine

Buhârî, Ebû Abdullah Muhammed. el-Câmiu's-sahîh. Beyrut: Dâru İbn Kesîr, 2003.

Câbirî, Muhammed Âbid. Arap-İslâm Siyasal Aklı. çev. Vecdi Akyüz. İstanbul: Kitabevi Yayinları, 2001.

Corci Zeydan. İslâm Uygarlıkları Tarihi. çev. Necdet Gök. İstanbul: İletişim Yayınları, 2012.

Demirci, Mustafa. "İktâ". Türkiye Diyanet Vakfi İslâm Ansiklopedisi. Erişim 24 Nisan 2020. https://islamansiklopedisi.org.tr/ikta

Demirci, Mustafa. İslâm'ın İlk Üç Asrında Toprak Sistemi. İstanbul: Kitabevi. 2003.

Dûrî, Abdülazîz. "Enbâr". Türkiye Diynet Vakfı İslâm Ansiklopedisi. Erişim 9 Temmuz 2020. https://islamansiklopedisi.org.tr/enbar

Dûrî, Abdülazîz. İlk Dönem İslam Tarihi. çev. Hayrettin Yücesoy İstanbul: Endülüs Yayınları, 2016.

Dûrî, Abdülazîz. İslam İktisat Tarihine Giriş. çev. Sabri Orman. İstanbul: İnsan Yayınları, 2014.

Ebû Dâvûd, Süleyman b. Eş'as es-Sicistâni el-Ezdî. Sünenu Ebî Dâvud. 2 Cilt. Beyrut: Dâru'rRisâletu'l-Âlemiye, 2009.

Ebû Ubeyd, Ebû Ubeyd, Kasım b. Sellam. Kitâbü'l-emvâl. thk. Dr. Muhammed Ammare. Beyrut: Darü'ş-Şuruk, 1989.

Ebû Yusuf, Ebû Yusuf Ya'kub b. İbrahim. Kitabü'l-harâc. Beyrut: Darü'l Ma'rife, 1979.

Ebu Zehra, Muhammed Ebu Zehra. İslâmda Sosyal Dayanışma. çev. Ethem Ruhi Fığlalı-Osman Eskicioğlu. İstanbul: Yağmur Yayınları, 1976.

Ekrem Ziyâ el-Ömerî. Asru'l-hilâfeti'r-raşide. Riyad: Mektebetu'l-Ubeykân, 2009.

Fayda, Mustafa. Allah'ın Kılıcı Halid b. Velid. İstanbul: İFAV Yayınları, 6. Basım, 2016.

Fayda, Mustafa. Hz. Ömer Zamanında Gayrimüslimler. İstanbul: MÜİF Yayınları, 1989.

Hârisî, Cureybe b. Ahmed b. Sünyâh el-Hârisî. Fıkhu'l-iktisâdî li emîri'l-mü'minîn Ömer b. ElHattâb. Cidde: Dâru'l-Endülüs, 2003.

Hüseyin Ali ed-Dakûkî. "Hîre”. Türkiye Diynet Vakfi İslâm Ansiklopedisi. Erişim 9 Temmuz 2020. https://islamansiklopedisi.org.tr/hire

İbn Hacer, Ebu'l-Fadl Ahmed b. Ali b. Muhammed b. Ahmed b. Hacer el-Askalânî. el-İsâbe fi temyizi's-sahabe. 8 Cilt. Beyrut: Daru'l-Kutubi'l-İlmiyye, 1415/1994.

İbn Kesîr, Ebu'l-Fida İsmail b. Ömer. el-Bidâye ve'n-nihâye. 15 Cilt. Beyrut: Mektebetu'l-Maârif, 1990.

İbn Manzûr, Ebü'l-Fazl Cemâlüddîn Muhammed b. Mükerrem b. Alî b. Ahmed el-Ensârî erRüveyfiî, Lisânü'l-'Arab, Beyrut: Daru'1-Sadir, 1414/1993.

İbn Sa'd, Muhammed b. Sa'd b. Menî ez-Zührî. Kitâbü't-tabakâti'l-kebîr. 11 Cilt. Kahire: Mektebetü'l-Hâncî, 2001.

İbn Şebbe, Ebu Zeyd Ömer b. Şebbe. Târîhu'l-medineti'l-münevvere. thk. Muhammed Şeltût. 4 Cilt. Cidde, 1399/1978. 
İbn Zebâle, Ebü'l-Hasen Muhammed b. el-Hasen b. Zebâle el-Medenî el-Mahzûmî. Ahbâru'lMedine. çev. Fatih Mehmet Yılmaz. Ankara: Ankara Okulu Yayınları, 2018.

İbn Zenceveyh, Ebû Ahmed Humeyd b. Mahled, Kitâbu'l-emval. Riyad: y.y., 1986.

İbnü'l-Esîr, İzzuddin Ebü'1 Hasan Ali b. Muhammed. el-Kâmil fi't-târih. thk. Ömer Abdusselam et-Tedmirî. 10 Cilt. Beyrut: Dârü'1 Kitâbi'l Arabiyye, 1417/1996.

İbrahim Muhammed, en-Nuzumu'l-maliyye fi'l-İslâm. Kâhire: el-Hey'etü'l-Misriyye, 1986.

Kal'ac'1, Muhammed Revvâs Kal'ac'1. Mu'cemu lugati'l-fukahâ. Dâru'n-Nefâis, 1988.

Kallek, Cengiz. Asr-ı Saâdet'te Yönetim-Piyasa İlişkisi. İstanbul: İz Yayıncılık, 1997.

Kayaoğlu, İsmet. İslâm Kurumlar Tarihi. Ankara: Ankara Üniversitesi Basımevi, 2. Basım, 1985.

Kettânî, Muhammed Abdulhay Kettânî. et-Teratibu'l-idâriyye. 2 Cilt. Beyrut,: Darü'1-Erkam b. Ebi'l-Erkam, ts.

Kureyşî, Gâlib b. Abdulkâfî. Evveliyâtu'l-fâruk fi'l-idâreti ve'l-kadâ. Beyrut: Müessesetu'lKutubi's-Sekâfiyye, 1990.

Lapıdus, Ira M. İslâm Toplumları Tarihi. çev. Yasin Aktay. İstanbul: İletişim Yayınları, 2005.

Mannan, Muhammad Abdul. İslâm Ekonomisi Teori ve Pratik. çev. Bahri Zengin-Tevfik Ömeroğlu. İstanbul: Fikir Yayınları, 1980.

Mâverdî, Ebu'l-Hasen Ali b. Muhammed b. Habîb el-Mâverdî. el-Ahkâmü's-sultaniyye. Kahire: Darü'l-Hadis, 2006.

Muhammad Hamidullah. el-Vesâiku's-siyâsiyye. çev. Vecdi Akyüz. İstanbul: Kitabevi, 1997.

Muhammed Hamidullah. İslam'da Devlet İdaresi. çev. Hamdi Aktaş İstanbul: Beyan Yayınları, 2016.

Muhammed Hamidullah. İslâm Peygamberi: (Hayatı ve Faaliyeti). çev. Salih Tuğ. 2 Cilt. İstanbul: İmaj Yayınevi, 2003.

Mușțafá Sibā‘ī. İslâm Sosyalizmi. çev. Yaşar Nuri Öztürk. İstanbul: Yeni Boyut, 2010.

Nezih Hammâd. Mu'cemu'l-mustalehâti'l-mâliyyeti ve'l-iktisâdiyyeti fi'l-luğati'l-fukahâ. Dımeşk,: Dâru'l-Kalem, 2008.

Oğuzay, Fatih. Hulefâ-i Râşidîn Döneminde Tarım Kültürü. İstanbul: Marmara Üniversitesi, Sosyal Bilimler Enstitüsü, Doktora Tezi, 2016.

Oğuzay, Fatih. Hz. Peygamber Döneminde Tarım Kültürüu. Sakarya: Sakarya Üniversitesi, Sosyal Bilimler Enstitüsü, Yüksek Lisans Tezi, 2008.

Ömer, Ahmed Muhtâr Abdulhamid. Mu'cemu'1-lugati'1-Arabiyyeti'1-Muâsıra. 4 Cilt. Kahire: Alemu'l-Kutub, 2008

Ömerî, Abdulaziz b. İbrahim. el-Vilayetu ala'l-buldan fi asri'l-hulafâi'r-raşidîn. Riyad: Dâru İşbiliyâ, 2001.

Özdemir, Mehmet Nadir. Hz. Peygamber Döneminde Ganimet Uygulamaları. Ankara: Otto Yayınlarl, 2016.

Rânâ, İrfan Mahmut Rânâ. Hz. Ömer Döneminde Ekonomik Yapı. çev. Ahmet Koç. İstanbul: Bir Yayıncilık, 1985.

Reyyis, Muhammed Ziyâüddîn. el-Harâc ve't-tanzimü'l-mâliyye fi'd-devleti'l-İslâmiyye. Kahire: Dâru'l-Meârif, 1969.

Sadr, Muhammed Bakır es-Sadr. İktisâdunâ. b.y.: el-Mecmeu'l-İlmiyye, 1408.

Semhûdî, Ebü'l-Hasen Nûrüddîn Alî b. Abdillâh, Vefâü'l-vefâ bi-ahbâri dâri'l-Mudtafâ. 4 Cilt. Beyrut: Daru'1-Kutubi'l-ìlmiyye, 1419/1987.

Sıddıkî, Selim A. İslâm Devletinde Mali Yapı. çev. Rasim Özdenören. İstanbul: Fikir Yayınları, 1968.

Söylemez, Mehmet Mahfuz. Bedevîlikten Hadârîliğe Kufe. Ankara: Ankara Okulu Yayınları, 2001. 
Söylemez, Mehmet Mahfuz. “Hz. Osman Dönemindeki Ekonomik Krizin Garnizyon Kentlere Etkisi-Kufe Örneği”. Gazi Üniversitesi Çorum İlahiyat Fakültesi Dergisi 2/3 (2003), 63-86.

Suyûtî, Celâluddîn Abdurrahmân b. Ebî Bekir es-Suyûtî. Mu'cem mekâlîdi'l-ulum fi'l-uudud ve'rrusûm. thk. Muhammed İbrahim. Kâhire: Mektebetu'l-Âdâb, 2004.

Taberî, Ebu Ca'fer Muhammed b. Cerîr. Târîhu'r-rusûl ve'l-mulûk. thk. Muhammed Ebû'l-Fadl İbrahim. 11 Cilt. Kahire: Dâru'l-Meârif, ts.

Yahya b. Âdem. Kitâbü'l-harâc. Kahire: Darü'l-Şuruk, 1987.

Ya'kūbî, Ebü'l-Abbâs Ahmed b. Ebî Ya'kūb İshâk b. Ca'fer b. Vehb b. Vâzıh el-Ya'kūbî. Kitâbü'l-büldân. Beyrut: Daru'l-Kutubi'l-İlmiyye, 1422/2001.

Yakut, Ebu Abdullah b. Abdillah. Mu'cemü'l-buldân. 5 Cilt. Beyrut: Dâru's-Sadr, 1977.

Yeniçeri, Celal. İslâm İktisadının Esasları. İstanbul: Şamil Yayınevi, 1980.

Yeniçeri, Celal. İslâm'da Devlet Bütçesi. İstanbul: Şamil Yayınevi, 1984. 